\title{
Interactions between investments in innovation and SME competitiveness in the peripheral regions
}

\author{
Anna Lewandowska \\ Department of Management, \\ University of Information Technology and Management in Rzeszoon, \\ Poland \\ alewandowska@wsiz.edu.pl
}

ORCID 0000-0002-5351-8490

\begin{abstract}
Since 2000 (The Lisbon Strategy), the discussion about the possible interactions between investments in innovation and competitiveness has become increasingly essential. Enterprises differ substantially with regard to their innovation activities, competitiveness and performance: size, sector, type of investment together determine their innovation activities. The main aim of this study is to analyze the roles of investments in innovation and how investments influence SME competitiveness in a peripheral region in Poland. The author investigates the effects of innovation activities among small and medium but also micro firms. The research was based on the data drawn from CATIs carried out among 808 firms (410 innovative and 398 non-innovative ones). To determine statistically significant differences between the variables of innovative and noninnovative companies, the logistic regression method was implemented. The research results show that among SMEs in the peripheral regions, not every type of investment affects competitiveness. The greatest dependence is demonstrated by the expenditures on machinery and equipment, on marketing activities, on intellectual property protection, and on training. The study also shows the existence of negative factors, the increase in which leads to a reduction in competitiveness level. Moreover, an innovative company which invests in innovation increases the chance of improving competitiveness more than a noninnovative company which invests in innovation.
\end{abstract}

Keywords: investments in innovation, competitiveness, SMEs, peripheral region, logistic regression.

JEL Classification: L11, L25, O31, R11 


\section{INTRODUCTION}

The issues of innovativeness and competitiveness in relation to enterprises, economies and territorial units are interrelated (Kot, 2006). Both innovativeness and competitiveness have become the concepts often referred to in economic theories as well as in practical activities in the recent years. In the modern global economy, competitiveness is the basic mechanism of development, and innovativeness is one of the ways to achieve it (Reichel, 2006). Competitiveness preconditioned by innovativeness and continuous technological progress is a challenge for countries and regions that want to develop. Under this approach, the issue of innovativeness, as a specific social process, is becoming more and more important for the development of every enterprise and economy. The relationship between investments in innovation and SMEs' competitiveness is crucial for a better understanding of the latter. Does more of implemented innovations result in a higher firm-level competitiveness?

Studies on the efficiency of innovation activity among SMEs exist but they tend to have ambiguous findings: in some cases we can find a positive relationship (more innovation, more competitiveness) or a negative relationship (more innovation, less competitiveness) (e.g., Lewandowska \& Stopa, 2019; Moen, 2018; Lejpras, 2015; Fitjar \& Rodríguez-Pose, 2011; Petrov, 2011). We think that the positive or negative relationship depends on the type of an investment in innovation. According to (Crescenzi, 2005), innovation activity can lead to different outcomes depending on a region. This may be due to the fact that peripheral regions might be able to provide an innovative environment for SMEs, while large firms rely on the wealthier environment in core regions (Karlsson \& Olsson, 1998). Innovations can create new markets where a firm has a monopolist status, therefore, innovation can directly affect competition (Kim \& Mauborgne, 2004). Most studies try to explain how companies in the peripheral regions can be more innovative despite the weaker potential (Eder, 2019). There is a need to study what differences occur in their innovation activity. This study is aimed to see which investment activities of enterprises will be effectively directed at improving competitiveness (or inaction). Similar studies have been carried out by (Negassi et al., 2019; Grillitsch et al., 2015; Eiriz et al., 2013), but there are no significant results for small companies. SMEs are important sources of innovation as they contribute to strengthening of the regional economy and competitiveness (Taymaz, 2005; Kliestik et al., 2020). We expect different results since the research has been conducted in a peripheral region. Practice shows that innovation is the key to business development, competitiveness and business growth. Companies must introduce new products and processes into production, create new organizational structures and new forms of marketing to achieve market success. Without thoroughly thought-out and planned investments in innovations and their implementation, bankruptcy of the company seems to be only a matter of time. However, on the other hand, it is relatively difficult to manage innovation, and the innovation process itself is difficult to maintain at an appropriate level. Investments in innovation and implementing innovations are both expensive and uncertain, and even innovations that are a technological success may not bring profit to organizations.

Podkarpackie is one of the least developed regions in Poland in terms of GDP per capita, labor productivity, and infrastructure. The challenge to SMEs in Podkarpackie is "increase in the competitiveness of an innovative enterprise in relation to other enterprises". Podkarpackie is classified as an EU peripheral where the effects of economic disadvantage have led to an EU modernization policy to "counteract the effects of peripherality". Innovation expenditures play a significant role in the development of innovation potential and overcoming the peripheral barriers. The RIS 2019 emphasizes that design applications are one of a few relative strengths in the regional innovation system of Podkarpackie. Others are: sales new-to-market/ firm innovations, $R \& D$ expenditures in the business sector, non-R\&D innovation expenditures, and tertiary education. Relative weaknesses observed in the local SME sector include: public-private co-publications, lifelong learning, and marketing or organizational innovations.. There are two very well developed fields in 
Podkarpackie: new IT technologies, and aeronautics \& space technology. Both of them are also smart specializations of Podkarpackie together with quality of life and the automotive industry. The Aviation Valley cluster has its headquarters in Rzeszów and the Informatyka Podkarpacka cluster operates also here. The Aviation Valley now has 160 enterprises and 30 thousand employees, while its sales volume reaches 3 bln USD. Over the past 15 years, these sales have increased elevenfold. The ICT determine the way economies are positioned within the globalization process, and the factual evidence suggests that ICTs have a strong regional dimension. In the European Commission study analyzing the place of the ICT industry in each of the approximately 1,300 regions within the EU, Podkarpackie is doing quite well. The Rzeszów subregion is the only region in Poland outside Warsaw that is present in the top 30. Namely, it was second in terms of employment growth across the EU. The Rzeszów subregion has also a very high rank in the category of increasing revenues from the IT industry since it was in the top 30 in the field of investments in the IT industry.

The aim of this paper is to explore SME investments in innovation and their impact on competitiveness in a peripheral region. Related to this aim are two crucial questions. Firstly, does being an innovative company increase the chance of being more competitive? Secondly, does every single type of investment in innovation affect growth and improve SME competitiveness? The author investigates the effects of innovation activities not only among small and medium entities, but also micro firms which are not covered in the official innovation surveys by the national statistical offices.

The research is based on the data drawn from CATIs carried out among 808 enterprises (410 innovative firms and 398 non-innovative ones). Differences between the variables of innovative and non-innovative companies were checked by the logistic regression method. These variables have an ordinal character in this study. Due to the small control group and large differences in the means for variables, it was decided not to use the propensity score matching (PSM) method.

The article is organized as follows. The first section of the paper presents the literature review on innovations and investments in innovation related to competitiveness, highlighting their connections and the impact of some investments on competitiveness along with the possibility of their joint examination. In the second section the author presents the description of methods and the data used. The third section consists of the presentation and discussion of the results. The paper ends with the concluding remarks.

\section{LITERATURE REVIEW}

A new concept of territorially oriented regional policy, i.e. a place-based policy, was the basis for creating the principles of cohesion policy in the programming period 2014-2020. The idea of developing territorial "smart specializations" occupies an important place in the concept of a new regional policy (Uyarra et al., 2018; Ranga, 2018; McCann \& Ortega-Argile's, 2016). It is assumed that in the current programming period, regional research and innovation strategies for smart specializations (RIS3) form the basis for the development and building of innovativeness and competitiveness of European Union regions (European Commission, 2014). According to the basic premise of the concept of smart specialization, regional development should be based on its endogenous potential (Berlińska, 2019; Burciu, 2017; Lopes et al., 2019). It is assumed that each territory should identify and designate its individual, specific and unique potentials resulting from its economic traditions, characterized by the highest development potential and creating opportunities for creating innovation. Smart specializations of the Podkarpackie region result from a choice, mainly based on the region's assets and endogenous resources. The main smart specializations of the Podkarpackie are aeronautics and space technology, quality of life, and the automotive industry. Ancillary smart specializations are found in Information and Telecommunications (Marshal's Office of the Podkarpackie Region, 2015). These are the economic sectors with the greatest development potential. The 
development of smart specializations in the regions is conducive to increasing their innovativeness and building a competitive advantage throughout the country and the world. The purpose of RIS3 is to ensure knowledge-based development by supporting national and regional investments, exploiting the potential of the country and regions, their strengths and competitive advantages, and supporting innovative potential, including stimulating innovative investments in the private sector (European Commission, 2014, 2-3).

In the times of a global economy, innovations are perceived as a way of overcoming difficulties, ensuring and preserving economic growth. Innovation can play a significant role in seeking new sustainable sources of growth and competitiveness (Galbraith et al., 2017). A permanent competitive advantage can be achieved primarily due to the growing innovative potential. Introducing new, significantly improved products, processes, and methods is becoming a key to productivity as well as job creation. During economic expansions companies increase innovation, while during economic contractions they decrease innovation (Lewandowska et al., 2019). Weakly developed regions lack the resources to be able to increase innovation during recessions in a Schumpeterian way. Similar conclusions have been reached in other research (Goraczkowska \& Tomaszewski, 2019). They indicate that business support organizations (BSOs) increase the chances of innovation activity, but their influence is different. Kokot-Stępień and Krawczyk (2020) confirmed the not significant impact of public support of innovative activity of enterprises. In another study Lewandowska and Stopa (2018) found that institutional support systems mitigate negative consequences of peripheral localization of the enterprises, where specific innovation strategy has no influence on SME assessment of innovation effectiveness. Innovation is too costly, and SMEs are too weak in peripheral regions, therefore there is a great need for reasonable and flexible institutional support systems. According to Florio et al. (2017) the most effective strategies to support SME innovation are represented by those more ambitious instruments that have a well specified logical intervention, focused objectives and selective targeting strategies.

An investment in innovation is an investment that creates the basis for being innovative, and then is implemented or contributes to the implementation of new products, processes or organizational solutions (Oslo Manual, 2005:29; PARP, 2007:23-24). Until the implementation, the investment is a potential investment in innovation and can represent the following types of activities: (1) Investments in machinery and equipment; (2) Investments in intellectual property; (3) Investments in knowledge. Competitiveness is a very differently defined concept. In general terms, competitiveness is about continuous existence (some call it "surviving") in the marketplace. In order to be able to do so, there is the need for a special ability to maintain and enhance market share (Leal Filho \& Weresa, 2007). Competitiveness should also reflect the changing needs and preferences of user groups and may involve providing the highest quality products and services at the lowest possible price. According to the Oslo Manual (2005:35), competitive advantage is achieved by improving the company's ability to be innovative (by increasing the ability to develop new products or processes or increasing and creating new knowledge).

On the basis of the theory, it has been proven that achieving a competitive advantage is possible only through innovative activities, and the ability of enterprises to innovate and to raise the technological level determines the competitiveness of the whole economy (Porter, 1990). Despite this, scientific research on the relationship between innovation and economic performance of enterprises does not give unequivocal solutions. It is both about the direction and strength of this relationship. In the 1990s, a professor at Harvard University, A. Bhide (2000), conducted in-depth interviews with hundreds of founders of young companies (not older than 8 years) that were on the Inc. list of 500 in the prestigious rankings in the US. The image of the entrepreneur of above-average success emerging from this research is surprising. Only 6 percent of respondents said they started their business with a unique product or service (Bhide, 2000: 32). In 58 percent of cases, identical or nearly identical substitutes were available on the market, and in 36 percent the 
substitutes differed only in functionality or price. So, the idea for a super-fast business was to imitate or only slightly adapt products or services already available on the market.

In the following years, intense attempts were made to examine the relationship between innovation and dynamic company development. They confirmed that high innovativeness is a factor, but not the only factor of business success. Such a conclusion was formulated, among others, in the OECD document on the basis of a review of many years of research on dynamic companies, where the final conclusion is: "The dynamics of growth is correlated with innovation, however the direction of this relationship is not clear" (OECD, 2013: 27). A similar conclusion results from a meta-review of the results of 42 empirical studies conducted in several dozen countries in the years 1990-2007, covering a total of over 2,000 companies, conducted by Rosenbusch et al. (2010). They find that, in general, innovations have a positive impact on the economic performance of enterprises. However, this relationship is conditioned by other factors, such as the company's age, type of innovation, as well as the company's organizational culture. A similar conclusion has been reached in other research (Audretsch et al., 2014). Szczygielski et al. (2017) Bilan et al. (2019) indicate that the impact of innovativeness on growth strongly depends on type of activity as well as type of innovation. Gkikas et al. (2014) assessed the level of importance of different types of innovation affecting and effecting high-growth in SMEs in an uncompetitive regional economy. They found that relationships with customers were most effective and important for business growth and leadership skills were found to be an important factor for implementing innovation. So how can one study the connection between investments in innovations and enterprise competitiveness? According to Porter (1998), these relations illustrate changes in labor productivity and capital. Sustained increase in efficiency requires continuous progress in the economy, and thus implementing innovations. Increasing the efficiency of enterprises and entire sectors is possible by improving the quality of products, modifying them, and improving technologies. This means that innovations lead to changes in competitive advantages, which ultimately is reflected in changes in the efficiency of production factors. Enterprises are developing thanks to investments in innovation and implementing of innovations, which allows companies to achieve competitive advantage over domestic and foreign rivals.

This research was conducted on firm-level data. To the author's knowledge, there are a few studies (see, for example, Moen et al., 2018; González-Pernía et al., 2012; Luchko et al., 2019; Mishchuk et al., 2016; Markowski, 2004; Report "Badanie wpływu...", 2009) on the relation between innovation and competitiveness, that are similar to this. Research by Markowski (2004) and Report "Badanie wpływu ..." (2009) has been very useful and provided a notion of innovations and competitiveness in Poland. Authors of the Report "Badanie wpływu ..." (2009) find effects of innovations and the impact these had on competitiveness of SMEs. But they used the method of the propensity score matching (PSM) and the analysis did not focus on peripheral regions. Berghäll (2016), for example, investigated how rigorous measures of innovation and the technology gap fare with respect to competitiveness in the Finnish ICT industry measured by the Lerner index. González-Pernía et al. (2012) tested the extent to which the capability of generating new knowledge and creating new firms are associated with regional competitiveness. In the study, however, the analysis did not include company perspective.

Some authors have investigated the opposite issue, which is what impact do competition and competitive conditions have on innovation? For example, Nguyen et al. (2016) investigated the comparative levels of efficiency, innovation and competition and then examined the effect of competition on innovation of banks. The research presented in this paper covers many aspects of the potential impact of investments of innovation on the competitiveness of SMEs. Anderson et al. (2001) indicate that peripheral regions can be "hostile environments for new and small firms" due to additional costs to manufacture or to service, and also to a limited pool of high qualified employees. 


\section{METHODOLOGY}

\subsection{Sample}

The analysis is based on a questionnaire from the project titled "The Study of the Impact of Investments in Innovation on the Competitiveness of the SME sector in Podkarpackie Voivodeship". The sample selection in the survey was carried out by a stratified sampling method according to the size of the enterprise (number of employees) and its sector (NACE rev. 2 section, please see: Eurostat 2008). The sampling criteria were rendered according to GDP contribution. Research was based on data drawn from CATIs carried out among 808 enterprises (410 innovative firms / research sample and 398 non-innovative firms/control sample). An innovative company is one that has implemented new or significantly improved solutions in relation to the process and / or product (or service) and / or marketing and / or organization in the last six years. A non-innovative company is one that hasn't implemented new or significantly improved solutions in relation to the process and / or product (or service) and / or marketing and / or organization in the last six years. Both samples were controlled in terms of company size. Both groups (innovative and non-innovative firms) answered questions about investment in innovation activities. The logistic regression method was used. Due to the small control group and large differences in means for variables, it was decided not to use the propensity score matching (PSM) method.

\subsection{Measures}

\section{Dependent variable}

The dependent variable in this study is a measure of competitiveness occurring in the enterprise under the influence of investment in innovation. A measure of competitiveness was measured by the effects of investment in innovation i.e.: rank of an improved product or service among other products, revenues from the market due to support of existing enterprise products, prices of products and services as a result of the depreciation costs of new equipment, quality of improved product or service in the eyes of customers, company market share, new markets, production flexibility, production efficiency, downtime and breakdowns, labor costs, amount of materials and energy, operating costs, sources of supply, new market structures, harmful activity enterprises, work safety, labor standards, and employees.

\section{Independent variables}

The first independent variable in this study is the firm's size. We used the number of micro, small and medium enterprises to measure this variable. The second explanatory variable is the enterprise sector. This was measured as the number of enterprises from agriculture, industry, construction, trade, transport, social affairs, and services. The third independent variable is the type of investment in innovations. We used in this regard: the expenditures on $\mathrm{R} \& \mathrm{D}$, the expenditures on machinery and equipment, expenditures on ICT, expenditures on intellectual property protection, expenditures on training, expenditures on marketing activities, and expenditures on the implementation of new solutions. Moreover, we used two type of innovation status of the firm: the innovative company and non-innovative company. We wanted to determine whether being an innovative firm increases the chance of being a more competitive firm.

The full set of variables that were tested as potentially significant is shown in Table 5 in the Appendix.

\subsection{Estimation}

The aim of the analysis was to examine the impact on the company's competitiveness factor, such as size (variable $\mathrm{X}_{1}$ ), sector (variable $\mathrm{X}_{2}$ ), type of investment in innovation (variable $\mathrm{Z}$ ) and whether the 
company is innovative or non-innovative (variable $\mathrm{P}_{1}$ ). The models examined various variables, where the dependent variable $\left(\mathrm{Y}_{\mathrm{i}}\right)$ is a measure of competitiveness (the effects of investment in innovation), which arises as a result of investments in innovation. The aim of the study is not to develop an optimal mechanism for determining the model. The aim is to determine statistically significant differences between the variables, such as size, sector, type of investment in innovation and whether the company is innovative or noninnovative.

$$
Y_{i} \sim B\left(p_{i}, n_{i}\right), \quad \text { for } \mathrm{i}=1, \ldots, \mathrm{m} .
$$

where the number of Bernoulli trials ni is known and the probability of success pi is unknown.

The model assumes that for each Beroulii trial (value i), there is a set of $\mathrm{k}$ independent variables that give some information about the probability of success. These independent variables can be considered as the k-element random vector $\mathrm{X}_{\mathrm{i}}$. Then the model takes the form:

$$
p_{i}=E\left(X_{i}\right) \text {. }
$$

The logit of the unknown probability of success pi is modeled as a linear function of Xi:

$$
\operatorname{logit}\left(p_{i}\right)=\ln \left(\frac{p_{i}}{1-p_{i}}\right)=\beta_{1} x_{1, i}+\beta_{2} x_{2, i}+\beta_{3} z_{i}+\varepsilon_{i}
$$

The model has an equivalent wording in the form:

$$
p_{i}=\frac{1}{1+e^{-\left(\beta_{1} x_{1, i}+\beta_{2} x_{2, i}+\beta_{3} z_{i}+\varepsilon_{i}\right)}} .
$$

When analyzing the impact of investments in innovations on competitiveness, a model was developed that took the form:

where:

$$
Y_{i}=\beta_{1} x_{1, i}+\beta_{2} x_{2, i}+\beta_{3} z_{i}+\varepsilon_{i}
$$

$\mathrm{Y}_{\mathrm{i}}$ - dependent variable (a measure of competitiveness (the effects of investment in innovation) occurring in the enterprise under the influence of investment in innovation, such as: rank of an improved product or service among other products, revenues from the market due to support of existing enterprise products, prices of products and services as a result of the depreciation costs of new equipment, quality of improved product or service in the eyes of customers, company market share, new markets, production flexibility, production efficiency, downtime and breakdowns, labor costs, amount of materials and energy, operating costs, sources of supply, new market structures, harmful activity enterprises, work safety, labor standards, employees)

$\mathrm{X}_{1}$ - company size (micro, small and medium enterprises); variable $\mathrm{X}_{1}$ takes values from 0 to 3

$\mathrm{X}_{2}$ - enterprise sector (agriculture, industry, construction, trade, transport, social affairs, services); $\mathrm{X}_{2}=$ $1, \ldots, 7$

$\mathrm{Z}$ - type of investments in innovations (expenditures on machinery and equipment, on ICT, on intellectual property protection, on training, on marketing activities, and expenditures on the implementation of new solutions); $Z=0$ or $Z=1$

$\varepsilon_{\mathrm{i}}$ - random component of the model

$\mathrm{i}=$ index indicating the enterprise, among the surveyed enterprises there are 410 innovative companies and 398 non-innovative companies; $i=1, \ldots ., 808$

First, a general measure of innovativeness was taken, and later a more accurate measure of innovativeness. In the last step, this more accurate measure was applied to all competitiveness measures (effects of investments in innovations). This made it possible to assess the marginal effect of changing investment in innovation to the level of competitiveness of SMEs. 


\section{EMPIRICAL RESULTS AND DISCUSSION}

Table 1 shows the descriptive statistics for the variables used in this research and Table 2 shows the correlation of variables used in this study indicating that the validity of variables is acceptable.

Table 1

Descriptive statistics

\begin{tabular}{|c|c|c|c|c|c|c|c|}
\hline & Variable & Obs. & Mean & Std. Dev. & Variance & Min & Max \\
\hline 1. & $\begin{array}{l}\text { The rank of an improved product } \\
\text { or service among other company } \\
\text { products }\end{array}$ & 729 & 1.00 & 1.147 & 1.315 & 0 & 3 \\
\hline 2. & $\begin{array}{l}\text { Revenues due to crowding out } \\
\text { existing company products from } \\
\text { the market }\end{array}$ & 698 & -.21 & .604 & .365 & -3 & 0 \\
\hline 3. & $\begin{array}{l}\text { Prices of products and services as } \\
\text { a result of depreciation costs of } \\
\text { new equipment }\end{array}$ & 722 & -.52 & .861 & .741 & -3 & 0 \\
\hline 4. & $\begin{array}{l}\text { The quality of the improved } \\
\text { product or service in the eyes of } \\
\text { customers }\end{array}$ & 751 & .86 & 1.172 & 1.374 & -3 & 3 \\
\hline 5. & Company's share in the market & 751 & .62 & 1.214 & 1.473 & -3 & 3 \\
\hline 6. & New markets & 717 & .29 & 1.146 & 1.313 & -3 & 3 \\
\hline 7. & Production flexibility & 717 & .50 & .985 & .969 & -3 & 3 \\
\hline 8. & Production efficiency & 724 & .57 & .986 & .972 & 0 & 3 \\
\hline 9. & Downtime and failures & 693 & -.08 & .370 & .137 & -3 & 0 \\
\hline 10. & Labor costs & 690 & .38 & .841 & .708 & 0 & 3 \\
\hline 11. & Amount of materials and energy & 694 & .27 & .716 & .512 & 0 & 3 \\
\hline 12. & Operating costs & 712 & -.44 & .847 & .718 & -3 & 0 \\
\hline 13. & Sources of supply & 714 & .20 & .718 & .516 & -3 & 3 \\
\hline 14. & New market structures & 716 & .03 & .644 & .415 & -3 & 3 \\
\hline 15. & $\begin{array}{l}\text { Harmfulness of the company's } \\
\text { activity }\end{array}$ & 718 & .24 & .702 & .492 & -3 & 3 \\
\hline 16. & Work safety & 726 & .50 & .897 & .804 & -1 & 3 \\
\hline 17. & Work standards & 747 & .66 & .990 & .981 & -2 & 3 \\
\hline 18. & Employees & 759 & .37 & .917 & .841 & -3 & 3 \\
\hline
\end{tabular}

Source: own calculation

Due to the level of feature measurement, a correlation matrix was made for the explained variable. The results are shown in Table 2. First, in the relationship between production flexibility and production efficiency, there were significant positive correlations between production flexibility and the production efficiency with $\mathrm{r}=.813(\mathrm{p}<0.01)$. Dependent variables are related to each other. As the value of production flexibility increases, the value of production efficiency increases. Next, as the value of the rank of an improved product or service among other company products increases, the improved product or service in the eyes of customers increases with $r=.668(\mathrm{p}<0.01)$, production efficiency increases with $\mathrm{r}=.610(\mathrm{p}<$ $0.01)$, company's share in the market increases with $r=.606(\mathrm{p}<0.01)$, production flexibility increases with $r=.536(p<0.01)$. Finally, as the value of labor costs increases, the amount of materials and energy with $r$ $=.630(\mathrm{p}<0.01)$.

The subject of the research is the recognition of the impact on the competitive factor of such company characteristics as size (variable $\mathrm{X}_{1}$ ), sector (variable $\mathrm{X}_{2}$ ), type of investment (variable $\mathrm{Z}$ ) and whether the company is innovative or non-innovative (variable $\mathrm{P}_{1}$ ).

In order to simulate the occurrence of the competitiveness factor, a logistic regression model was constructed. This model was created on the basis of observations made on a group of randomly 808 selected companies that took part in the CATI study. The following method of variable coding has been adopted: 
- in the size range: micro - 1 , small - 2, medium - 3 ,

- in the sector range: agriculture - 1 , industry - 2 , construction -3 , trade - 4 , transport - 5 , social affairs -6 , services -7 ,

- in the type of investments in innovations: expenditures on machinery and equipment, expenditures on ICT, expenditure on intellectual property protection, expenditure on training, expenditures on marketing activities, expenditures on the implementation of new solutions: expended - 1, not expended - 0 ,

- in the innovativeness range: innovative company - 1, non-innovative company - 0.

Taking into account the characteristics of enterprises that are innovative and the characteristics of enterprises that are non-innovative, it was necessary to estimate the logistic regression equation with three types of independent variables.

Table 3 summarizes the results of the random sample from the logistic regression model. Not all regressors were statistically significant. There were many statistically significant relationships with positive and negative impacts on the competitiveness of companies. Table 3 clearly shows that the competitiveness of SMEs (effects of innovations implemented) differed depending on the type of investment.

\section{Factors stimulating SME competitiveness}

Enterprises investing in machinery and equipment and marketing activities strongly influence (strong statistical dependence) the increase of the rank of improved product / service among other company products, improvement of the quality of improved product / service in the eyes of customers, improvement of flexibility and production efficiency and reduction of labor costs (in the case of the latter, a relationship was observed with expenditures on machines and devices as well as expenditures on intellectual property protection). The estimated coefficients $(\mathrm{z} 1=0.981064,0.72508,1.075819,1.16881$, and 1.380924; z5 = $0.840005,0.70669,0.798799$, and 0.8892 ) are statistically significant at the 0 level. The same applies to expenditure on intellectual property protection - a strong impact on the creation of new market structures, reduction of health and environmental impact of the company's functioning, increase in work safety, and reduction of labor costs per product was observed.

Weak dependence (however, still statistically significant) was observed in the case of expenditure on intellectual property protection - there is an improvement in the quality of the improved product / service in the eyes of customers, reduction of the amount of materials and energy per product, development of supply sources, improvement of work standards and employment new employees. The estimated coefficient ( $z 3=0.51237,0.6082,0.44261$, and 0.577843$)$ is statistically significant at the 0.01 level. Similarly, with the expenses for marketing activities - it is clear in developing sources of supply and reducing the harmfulness to the health and environment of the company. Enterprises that have expenditures for the implementation of new solutions affect the creation of new market structures and reduce the harm to the health and environment of the company's operations. And those companies that spend more on training affect employment growth.

That is, on average, enterprises investing in machinery and equipment and marketing activities achieve a higher level of competitiveness than enterprises investing in intellectual property protection, training or implementation of new solutions. This result supports in the part the arguments of other authors (Squicciarini, 2017; Report “Badanie wpływu ...”, 2009).

\section{Factors destabilizing SME competitiveness}

A statistically significant dependence of the negative impact of expenditures was also observed. For example, companies spending more on machinery and equipment affect the increase in prices of products 
and services as a result of the cost of depreciation of new equipment and the increase in operating costs of new machines. All the estimated coefficients are negative $(z 1=-0.68566$ and -0.97307$)$ and statistically significant at the 0 level. Similarly, the expenses for the implementation of new solutions show a weak statistically significant relationship with the reduction of production flexibility. The estimated coefficient (z6 $=0.733465)$ is statistically significant at the 0.01 level.

Next, the marginal effect of changing investments in innovations to the level of competitiveness was calculated. The results are presented in Table 4.

Regarding the interpretation of the marginal effect of changing investment in innovation on the level of competitiveness of SMEs, the values of the model indicate that the rank of the improved product or service, the quality of the improved product or service, flexibility and production efficiency, as well as the operating costs show a statistically significant relationship with expenditures on machines and devices and expenditures on marketing activities. For example, spending on machinery and equipment increases the chance of increasing the rank of an improved product or service among other company products by 167 percent, improving the quality of the improved product / service in the eyes of customers by 106 percent, improving the production flexibility by 193 percent, and production efficiency by 222 percent. The same is true of the costs of protecting intellectual property - it increases the chances of creating new market structures by 195 percent, reducing the harmfulness of business operations by 141 percent, improving work safety by 86 percent, reducing labor costs by 95 percent. In turn, expenses for training increase the chance of employing new employees by 150 percent and increase of the company's market share by 53 percent.

Being an innovative company increases the chance of becoming more competitive, for example, being innovative increases the chance of increasing the rank of an improved product / service among other company products by 703 percent. The analysis confirmed a statistically significant relationship between the company's introduction of another type of innovation and almost all factors of SME competitiveness. In the majority of competitiveness factors, the ratio is significant at the level of 0.001 . For example, the introduction of each subsequent type of innovation increases the chance of increasing the rank of an improved product or service among other company products by 151 percent, improving the quality of an improved product / service in the eyes of customers by 102 percent, improving production efficiency by 83 percent, and increasing the company's market share by 70 percent. There was no statistically significant relationship between the introduction of another type of innovation and the change in revenues caused by the support from the market of the company's existing products. This suggests that innovative companies achieve greater effects of innovations implemented (benefits and costs) than non-innovative enterprises. This empirical finding is an interesting contribution to the extant literature, because it proves Audretsch's argument that both innovation and innovation capacities together are important drivers of firm growth and its competitiveness (Audretsch et al., 2014).

\section{CONCLUSION}

SME are more and more often engaged in innovative activities. Enterprises can achieve many economic benefits, above all that they remain on the market and compete with other entities by focusing on various types of improvements and new products.

The study explains how the characteristics of the surveyed enterprises (size of the scale), the type of investment, and the fact of implementing another type of innovation affect SME competitiveness. The results of the research showed that the size of the company affects the improvement of labor standards and employment growth, and to a lesser extent the increase in the company's market share. As far as industries 
are concerned, the highest statistically significant dependence on the occurrence of competitiveness has been demonstrated by the industrial sector (relation to production flexibility, labor costs, company market share and new markets), trade sector (relation to revenues, price of products / services, operating costs, costs work, labor standards, the amount of materials and energy), the construction industry (relation to operating costs and labor costs) and the transport industry (connection with employees).

When answering the research questions, two issues should be noted. First, being an innovative company increases the chance of becoming more competitive. An innovative company which invests in innovation increases the chance of improving competitiveness more than a non-innovative company which invests in innovation. Second, it is important that not every type of investment affects (shows statistically significant dependence) the competitiveness of SMEs. The greatest dependence is on expenditures on machinery and equipment, expenditures on marketing activities, expenditures on intellectual property protection, expenditures on training, and expenditures on the implementation of new solutions. The probable reason for the relationship between expenditures on machinery and equipment and the majority of competitiveness factors is the fact that expenditures on innovations leads to improved productivity and production flexibility, lower labor costs, and new products, which increases the value of sales, however increasing operating costs.

It is difficult to indicate a clear reason for the lack of dependency between expenditures on machinery and equipment and variables that determine the value of revenues due to market support of the company's existing products. The first reason may be that the value of incurred expenditures is too low to find here any dependence. And only at higher expenditures and their greater variance would it be possible to determine. The second probable cause of the difficulty in estimating the actual dependence is its long-term nature. Expenditures on ICT incurred in many companies have a chance at pay back only after a long period of time. Meanwhile, a sample covering a relatively short period makes it impossible to check the existence of dependence over a longer time horizon. In the case of expenditure on ICT, no statistically significant impact on the occurrence of any factor of competitiveness was noted. However, it is difficult to believe in the actual lack of this relationship. One can only assume that in this case the main reason for not confirming the dependence is that the total value of expenditures is too low for their impact in this field to be noticeable. This is consistent with the literature. Arendt and Grabowski (2017) argued that the relationship between innovation, ICT and productivity is more complex and depends on a company's distance to the technological frontier. In other words, the more productive a company is, the more effort in terms of coinnovative sources of productivity is required to boost productivity by introducing new technologies (including ICT). Moreover, the results confirmed that the investments in and the use of ICT are significant factor of the innovativeness of SMEs (Torrent-Sellens \& Ficapal-Cusi, 2010).

The study also showed the existence of negative factors, which, by increasing their size, lead to a reduction in the level of competitiveness. First, the more innovative companies spend on machinery and equipment the more they increase the prices of products and services as a result of the cost of depreciation of new equipment and the increase in operating costs of new machines. Moreover, expenditures on the implementation of new solutions reduce production flexibility.

It must be noted that the presented results refer to the term "innovation" as the improvement that is made at least on a company level, and not necessarily an introduction of a solution that is new to the region, country or the world. Moreover, developing regions such as Podkarpackie are fund-sensitive because companies have limited access to finance high-risk activities including innovations. It has been argued that some types of funding did not contribute to permanent improvement but served only as demand factors. We think that this type of innovative activity has a chance for success only if it invests in an appropriate type of investment. The periphery is changing, and the changes may well be driven by the growth of SMEs as a result of investments in innovation. The entrepreneurs through the operation of their businesses have 
an important role in fixing change. These changes are economies of innovative activities, in contrast to the passive operation of companies without appropriate type of investments.

In most cases, the obtained results confirm the conclusions from other studies devoted to the analysis of effectiveness of investment and innovation activity in the small and medium-sized enterprise sector (Arendt \& Grabowski, 2019, 2017; Lewandowska \& Stopa, 2019; Moen, 2018; Szczygielski et al., 2017; Kim \& Mauborgne, 2004). It should be noted that the conclusions from this paper considerably develop the existing knowledge about effectiveness of different types of investments in innovation. The originality of the approach presented in this paper relies on comparing results among innovative and non-innovative firms, and examination of effectiveness of many different types of investments in innovation and using the logistic regression method.

The author's main contribution is the identification of how the characteristics of the surveyed enterprises, the type of investment, and the fact of implementing another type of innovation affect competitiveness. In further studies, this approach should be further developed by, for example, focusing on the impact of cooperation on scale and quality of SME innovation activities. Evaluation of SME cooperation with different businesses, $\mathrm{R}+\mathrm{D}$, universities and others would be very useful for strategic effectiveness.

\section{ACKNOWLEDGEMENT}

This research was performed as project as «The Study of the impact of investments in innovation on the competitiveness of the SME sector in Podkarpackie voivodship» (2014-2016) which was financed from the funds granted to the University of Information Technology and Management as a grant for the maintenance of research potential.

The author is grateful for the helpful critiques and comments received from colleagues at Rzeszów, especially Elżbieta Inglot-Brzęk and Robert Pater.

\section{REFERENCES}

Anderson, A., Jack, S., \& McAuley, A. (2001). Periphery? What periphery? Marketing to a state of mind. Marketing Review 14(1), 26-34. https://doi.org/10.21427/D7DN1V

Arendt, Ł., \& Grabowski, W. (2017). Innovations, ICT and ICT-drive labour productivity in Poland. A firm level approach. Economics of Transition, 25(4), 723-758. https://doi.org/10.1111/ecot.12135.

Arendt, L., \& Grabowski, W. (2019). The role of firm-level factors and regional innovation capabilities for Polish SMEs. Journal of Entrepreneurship, Management and Innovation, 15(3), 11-44. https://doi.org/10.7341/20191531.

Audretsch, D.B., Coad, A., \& Segarra, A. (2014). Firm growth and innovation. Small Business Economics, 43(4), 743-749. https://doi.org/10.1007/s11187-014-9560-x

Berghäll, E. (2016). Innovation, competition and technical efficiency. Cogent Business \& Management, 3(1), 1-23. https://doi.org/10.1080/23311975.2016.1199522

Berlińska, E. (2019). Smart specialisations - comparative analysis of selected polish regions using the location quotient. Scientific papers of Silesian University of Technology Organization and Management series No. 139, 37-47.

Bhide, A.V. (2000). The origin and evolution of new business. Oxford: Oxford University Press.

Bilan, Y., Rubanov, P., Vasylieva, T., \& Lyeonov, S. (2019). The influence of industry 4.0 on financial services: Determinants of alternative finance development. Polish Journal of Management Studies, 19(1), 70-93.

Burciu, A. (2017). Technology and labour market in the European Union. Economics, Management and Sustainability, 2(1), 36-42. https://doi.org/10.14254/jems.2017.2-1.3.

Crescenzi, R. (2005). Innovation and Regional Growth in the Enlarged Europe: The Role of Local Innovative Capabilities, Peripherality, and Education. Growth and Change, 36 (4), 471-507. https://doi.org/10.1111/j.14682257.2005.00291.x.

Eder, J. (2019). Innovation in the Periphery: A Critical Survey and Research Agenda. International Regional Science Review, 42(2), 119-146. https://doi.org/10.1177/0160017618764279. 
Eiriz, V., Faria, A., \& Barbosa N. (2013). Firm growth and innovation: Towards a typology of innovation strategy. Innovation: Management, Policy \& Practice 15(1), 97-111. https://doi.org/10.5172/impp.2013.15.1.97.

European Commission. (2014). European Commission National / regional innovation strategies for smart specialization (RIS3). Available online https://ec.europa.eu/regional_policy/sources/docgener/informat/2014/smart_specialisation_en.pdf, 29 June 2020.

Eurostat 2008. NACE Rev. 2 Statistical classification of economic activities in the European Community. [available online 19.01.2017 http:/ / ec.europa.eu/eurostat/documents/3859598/5902521/KS-RA-07-015-EN.PDF].

Fitjar, R. D., \& Rodríguez-Pose, A. (2011). Innovating in the Periphery: Firms, Values and Innovation in Southwest Norway. European Planning Studies 19 (4), 555-74. doi: 10.1080/09654313.2011.548467.

Florio M., Vallino, E., \& Vignetti, S. (n.d.). How to Design Effective Strategies to Support SMEs Innovation and Growth During the Economic Crisis: Lessons from Ex-post Evaluation of 2007-2013 ERDF Programmes.

Galbraith, B., McAdam, R., Woods, J., \& McGowan, T. (2017). Putting policy into practice: an exploratory study of SME innovation support in a peripheral UK region. Entrepreneurship \& Regional Development 29(7-8), 668-691. https://doi.org/10.1080/08985626.2017.1325939

Gkikas, A., Jones-Evans, D., \& MacKenzie, N. (2014). Effectiveness and Importance of Innovation on Business Performance in an uncompetitive region: Evidence from High-Growth SMEs in Wales. International Council for Small Business. World Conference Proceedings. 1/1/2014, 1-2.

González-Pernía, J.L., Peña-Legazkue, I., \& Vendrell-Herrero, F. (2012). Innovation, entrepreneurial activity and competitiveness at a sub-national level. Small Business Economics 39(3), 561-574. https://doi.org/10.1007/s11187-011-9330-y

Gorączkowska, J., \& Tomaszewski, M. (2019). Support of innovation activity in small and medium-sized enterprises in the Greater Poland Voivodeship. Ekonomia $i$ Prawo. Economics and Law, 18(2), $183-195$. https://doi.org/10.12775/EiP.2019.014.

Grillitsch, M. and Nilsson, M. (2015). Innovation in peripheral regions: Do collaborations compensate for a lack of local knowledge spillovers? Ann Reg Sc 54(3), 299-321. https://doi.org/10.1007/s00168-014-0655-8.

Karlsson, C., \& Olsson, O. (1998). Product Innovation in Small and Large Enterprises. Small Business Economics 10(1), 31-46. https://doi.org/10.1023/a:1007970416484.

Kim, W. C., \& Mauborgne, R. (2004). Blue ocean strategy. Harvard Business Review, 82(10), 76-84.

Kliestik, T., Valaskova, K., Lazaroiu, G., Kovacova, M., \& Vrbka, J. (2020). Remaining Financially Healthy and Competitive: The Role of Financial Predictors. Journal of Competitiveness, 12(1), 74-92.

Kokot-Stępień, P., \& Krawczyk, P. (2020). The impact of public support on innovative activity of enterprises. Ekonomia $i$ Prawo. Economics and Law, 19(2), 291-304. https://doi.org/10.12775/EiP.2020.020.

Kot, J. (2006). Innowacyjność i konkurencyjność regionu. Raport zbiorczy z badań przeprowadzonych w Zespole badawczym - Gospodarka i Przedsiębiorstwa. Kielce: Uniwersytet Humanistyczno-Przyrodniczy w Kielcach.

Leal Filho, W., \& Weresa M. (eds.) (2007) Achieving Competitiveness Through Innovations - A Challenge for Poland and Other New EU Member States. Frankfurt am Main: Peter Lang Europäischer Verlag der Wissenschaften.

Lejpras, A. (2015). Knowledge, location, and internationalization: empirical evidence for manufacturing SMEs. Economics of Innovation \& New Technology 24(8), 734-754. https:// doi.org/10.1080/10438599.2014.997460.

Lewandowska, A., \& Stopa, M. (2018). SME's Innovativeness and Institutional Support System: The Local Experiences in Qualitative Perspective. Oeconomia Copernicana. Quarterly Journal, 9(2), 333-351. https://doi.org/10.24136/oc.2018.017

Lewandowska, A., \& Stopa, M. (2019). Do SME's innovation strategies influence their effectiveness of innovation? Some evidence from the case of Podkarpackie as peripheral region in Poland, Equilibrium. Quarterly Journal of Economics and Economic Policy, 14(3), 521-536. https://doi.org/10.24136/eq.2019.025

Lewandowska, A., Pater, R., \& Cywiński, Ł. (2019). Determinants of business innovation in the Regional Innovation System context. Policy implications for a less developed region. Studia regionalne $i$ lokalne, 1(75), 5-27. https://doi.org/10.7366/1509499517501.

Lopes, J., Ferreira, J.J., \& Farinha, L. (2019). Innovation strategies for smart specialization (RIS3): Past, present and future research. Growth and Change,50:38-68. https://doi.org/10.1111/grow.12268 
Luchko, M., Ruska, R., Lew, G., \& Vovk, I. (2019). Modelling the optimal size of investment portfolio in a non-state pension fund. Journal of International Studies, 12(1), 239-252.

Markowski T. (2004) Konkurencyjność i innowacyjnośćpolskich regionów wobec akcesji do UE, (w:) Ekonomiczno organizacyjne uwarunkowania rozwoju regionu, Wydawnictwo Uniwersytetu Lódzkiego.

Marshal's Office of the Podkarpackie Region (2015). Regional Innovation Strategy of the Podkarpackie Voivodeship for smart specialization (RIS3) 2014-2020. Available online http://rpo.podkarpackie.pl/images/dok/15/RSI_2014_2020_wersja_angielska.pdf, 29 June 2020.

McCann, P., \& Ortega-Argile's, R. (2016). Smart specialisation, entrepreneurship and SMEs: Issues and challenges for a results-oriented EU regional policy. Small Bus Econ, 46, 537-552. https://doi.org/10.1007/s11187-016-9707z.

Mishchuk, H., Bilan, Y., \& Pavlushenko, L. (2016). Knowledge management systems: Issues in enterprise human capital management implementation in transition economy. Polish Journal of Management Studies, 14(1), 163-173.

Moen, Ø., Tvedten, T., \& Wold, A. (2018). Exploring the relationship between competition and innovation in Norwegian SMEs. Cogent Business \& Management, 5(1), 1-15. https://doi.org/10.1080/23311975.2018.1564167

Negassi, S., Lhuillery, S., Sattin, J.F., Hung, T.Y., \& Pratlong, F. (2019). Does the relationship between innovation and competition vary across industries? Comparison of public and private research enterprises, Economics of Innovation and New Technology, 28(5), 465-482, https://doi.org/10.1080/10438599.2018.1527552

Nguyen, T.P.T., Nghiem, S.H., Roca, E., \& Sharma, P. (2016). Efficiency, innovation and competition: evidence from Vietnam, China and India. Empirical Economics, 51(3), 1235-1259. https://doi.org/10.1007/s00181-015-1045-5

OECD (2013). New Entrepreneurs and High Performance Enterprises in the Middle East and North Africa. Paris: OECD.

Oslo Manual: Proposed Guidelines for Collecting and Interpreting Technological Innovation Data. 3rd Edition. 2005. OECD, Eurostat. [available online, 20.02.2017 http://www.oecd.org/dataoecd/35/61/2367580.pdf.

Petrov, A. (2011). Beyond Spillovers. Interrogating Innovation and Creativity in the Peripheries. In Beyond Territory. Dynamic Geographies of Knowledge Creation, Diffusion, and Innovation, edited by Harald Bathelt, Maryann P. Feldman, and Dieter Kogler, 149-67. New York: Routledge.

Porter, M. (1990). The Competitive Advantage of Nations. New York: The Free Press.

Porter, M. (1998). On Competitiveness. New York: The Free Press.

Ranga, M. (2018). Smart specialization as a strategy to develop early-stage regional innovation systems. European Planning Studies, 26(11), 2125-2146. https://doi.org/10.1080/09654313.2018.1530149

Raport „Badanie wplywu inwestycji w innowacje na konkurencyjność przedsiębiorstw / sektora MSP w wojewódźtwie ślaskim”. Urząd Marszałkowski Województwa Śląskiego, Katowice 2009.

Regional Innovation Scoreboard 2019. (2019). Brussels: European Commission.

Reichel, M. (2006). Potencjał innowacyjny Polski południowo-wschodniej w strukturach subregionalnych. PWSZ, Nowy Sącz; Strategia Rozwoju Kraju 2020, Ministerstwo Rozwoju Regionalnego, Warszawa 2012.

Rosenbusch, N. Brinckmann, J., \& Bausch, A. (2010). Is innovation always beneficial? A meta-analysis of the relationship between innovation and performance in SMEs. Journal of Business Venturing 26(4), 441-457.

Squicciarini, M. (2017). Entrepreneurship, innovation and enterprise dynamics. Small Business Economics 48(2), 335-350. https://doi.org/10.1007/s11187-016-9784-z

Szczygielski K., Grabowski W., \& Woodward R. (2017), Innovation and the growth of service companies: the variety of firm activities and industry effects. Industry and Innovation, 24(3), 249-262.

Taymaz, E. (2005). Are Small Firms Really Less Productive? Small Business Economics, 25(5), 429-445. https://doi.org/10.1007/s11187-004-6492-x

Torrent-Sellens, J., \& Ficapal-Cusi, P. (2010). New co-innovating sources of business productivity?. Innovar, 20(38), $111-124$

Uyarra, E., Marzocchi, Ch., \& Sorvik, J. (2018). How outward looking is smart specialisation? Rationales, drivers and barriers. European Planning Studies 26(12), 2344-2363. https:/ / doi.org/10.1080/09654313.2018.1529146 


\section{APPENDIX}

Table 2

Correlation matrix

\begin{tabular}{|c|c|c|c|c|c|c|c|c|c|c|c|c|c|c|c|c|c|c|c|}
\hline \multicolumn{2}{|l|}{ Variable } & 1 & 2 & 3 & 4 & 5 & 6 & 7 & 8 & 9 & 10 & 11 & 12 & 13 & 14 & 15 & 16 & 17 & 18 \\
\hline \multirow{3}{*}{$\begin{array}{l}\text { 1.The rank of an } \\
\text { improved product or } \\
\text { service among other } \\
\text { company products }\end{array}$} & PC & 1 & & & & & & & & & & & & & & & & & \\
\hline & Significance & & & & & & & & & & & & & & & & & & \\
\hline & $\mathrm{N}$ & 729 & & & & & & & & & & & & & & & & & \\
\hline \multirow{3}{*}{$\begin{array}{l}\text { 2. Revenues due to } \\
\text { crowding out existing } \\
\text { company products from } \\
\text { the market }\end{array}$} & PC & \begin{tabular}{|l|l|l|}
,- 006 \\
\end{tabular} & 1 & & & & & & & & & & & & & & & & \\
\hline & Significance & \begin{tabular}{|l|l|}
, 871 \\
\end{tabular} & & & & & & & & & & & & & & & & & \\
\hline & $\mathrm{N}$ & 677 & 698 & & & & & & & & & & & & & & & & \\
\hline \multirow{3}{*}{$\begin{array}{l}\text { 3. Prices of products } \\
\text { and services as a result } \\
\text { of depreciation costs of } \\
\text { hew equipment }\end{array}$} & PC &,$- 343^{\text {tat }}$ & $247^{* *}$ & 1 & & & & & & & & & & & & & & & \\
\hline & Significance & 0 &, 000 & & & & & & & & & & & & & & & & \\
\hline & N & 692 & 675 & 722 & & & & & & & & & & & & & & & \\
\hline \multirow{3}{*}{$\begin{array}{l}\text { 4. The quality of the } \\
\text { improved product or } \\
\text { service in the eyes of } \\
\text { customers }\end{array}$} & $\mathrm{PC}$ &, $668^{* * 4}$ & ,062 &,$- 271^{\text {*n }}$ & 1 & & & & & & & & & & & & & & \\
\hline & Significance & 000 & 104 & ,000 & & & & & & & & & & & & & & & \\
\hline & $\mathrm{N}$ & 716 & 688 & 713 & 751 & & & & & & & & & & & & & & \\
\hline \multirow{3}{*}{$\begin{array}{l}\text { 5. Company's share in } \\
\text { the market }\end{array}$} & PC & ,606 & $301^{* 4}$ &,$- 204^{* * 4}$ &, $586^{* *}$ & 1 & & & & & & & & & & & & & \\
\hline & Significance & 000 &, 000 & 000 & ,000 & & & & & & & & & & & & & & \\
\hline & $\mathrm{N}$ & 717 & 685 & 708 & 731 & 751 & & & & & & & & & & & & & \\
\hline \multirow[t]{3}{*}{ 6. New markets } & $\mathrm{PC}$ & $389^{* *}$ & $228^{*+4}$ & \begin{tabular}{|c|}
,- 057 \\
\end{tabular} & $349^{* * *}$ &, $641^{* *}$ & 1 & & & & & & & & & & & & \\
\hline & Significance &, 000 &, 000 & ,138 & ,000 &, 000 & & & & & & & & & & & & & \\
\hline & $\mathrm{N}$ & 689 & 672 & 688 & 706 & 707 & 717 & & & & & & & & & & & & \\
\hline \multirow[t]{3}{*}{ 7. Production flexibility } & PC &, $536^{* *}$ &, $081^{*}$ &,$- 291^{* *}$ &, $502^{* *}$ &, $521^{* *}$ & $397^{* *+}$ & 1 & & & & & & & & & & & \\
\hline & Significance &, 000 &, 037 &, 000 &, 000 &, 000 &, 000 & & & & & & & & & & & & \\
\hline & $\mathrm{N}$ & 693 & 670 & 683 & 703 & 703 & 689 & 717 & & & & & & & & & & & \\
\hline \multirow[t]{3}{*}{ 8. Production efficiency } & $\mathrm{PC}$ &, $610^{* *}$ &,- 057 &,$- 408^{* 4}$ & $517^{* *}$ &, $525^{* *}$ & $374^{* *+}$ & $.813^{* *}$ & 1 & & & & & & & & & & \\
\hline & Significance & 000 &, 140 &, 000 & ,000 &, 000 & ,,000 & ,000 & & & & & & & & & & & \\
\hline & $\mathrm{N}$ & \begin{tabular}{|l|}
695 \\
\end{tabular} & 673 & 691 & 710 & 709 & 691 & 706 & 724 & & & & & & & & & & \\
\hline \multirow{3}{*}{$\begin{array}{l}\text { 9. Downtime and } \\
\text { failures }\end{array}$} & PC &,$- 148^{* 4}$ & $257^{*+4}$ & $175^{* *}$ & $-0,064$ &,- 069 &,- 058 &,- 071 &,$- 147^{* * 4}$ & 1 & & & & & & & & & \\
\hline & Significance & 0,000 &, 000 & ,000 & ,097 & ,070 & , 134 &, 065 & ,000 & & & & & & & & & & \\
\hline & $\mathrm{N}$ & 670 & 651 & 671 & 681 & 683 & 669 & 676 & 681 & 693 & & & & & & & & & \\
\hline \multirow[t]{3}{*}{ 10. Labor costs } & PC &, $512^{* *}$ &, $115^{* *}$ &,$- 355^{* *}$ &, $447^{* *}$ &, $428^{* *}$ & $287^{* *}$ & ,604 &, $682^{* *}$ &,$- 258^{* *}$ & 1 & & & & & & & & \\
\hline & Significance & 0,000 & ,004 & ,000 & ,000 & 000 & ,000 &, 000 & 000 & ,000 & & & & & & & & & \\
\hline & $\mathrm{N}$ & 664 & 644 & 659 & 676 & 673 & 664 & 673 & 678 & 659 & 690 & & & & & & & & \\
\hline \multirow{3}{*}{$\begin{array}{l}\text { 11. Amount of materials } \\
\text { and energy }\end{array}$} & PC &, $441^{* *}$ &,- 058 &,$- 225^{5 *}$ & $381^{* *}$ & $377^{* *}$ & $256^{* * *}$ &, $498^{* *}$ &, $532^{* *}$ &,$- 318^{* *}$ &, $630^{* *}$ & 1 & & & & & & & \\
\hline & Significance & 000 &, 139 &, 000 &, 000 &, 000 &, 000 &, 000 &, 000 &, 000 &, 000 & & & & & & & & \\
\hline & $\mathrm{N}$ & 665 & 650 & 662 & 682 & 676 & \begin{tabular}{|l|}
669 \\
\end{tabular} & 673 & 679 & 660 & 679 & 694 & & & & & & & \\
\hline 12. Operating costs & PC &,$- 353^{* *}$ & $215^{* 4}$ &, $569^{* *}$ &,$- 257^{* *}$ &,$- 176^{6+\infty}$ & \begin{tabular}{|c|}
,- 047 \\
\end{tabular} &,$- 317^{* 4}$ &,$- 418^{* *}$ &, $156^{* *}$ & $-368^{* *}$ & $-259^{* * 4}$ & 1 & & & & & & \\
\hline & Significance & 0,000 & ,000 & ,000 & ,000 & ,000 & ,223 & ,000 & ,000 & ,000 & ,000 &, 000 & & & & & & & \\
\hline & $\mathrm{N}$ & 683 & 670 & 687 & 704 & 697 & 684 & 684 & 689 & 672 & 666 & 677 & 712 & & & & & & \\
\hline 13. Sources of supply & PC &, $309^{* *}$ &, 029 &,$- 144^{* *}$ &, $227^{* *}$ &, $224^{* *}$ & $255^{* * 4}$ & $306^{* *}$ & $269^{* *}$ & ,019 & $228^{* *}$ & $133^{* *}$ &,$- 096^{*}$ & 1 & & & & & \\
\hline & Significance &, 000 &, 458 &, 000 &, 000 &, 000 &, 000 &, 000 &, 000 & 621 & 000 & 001 & 011 & & & & & & \\
\hline & $\mathrm{N}$ & 682 & 672 & 687 & 704 & 699 & 685 & 683 & 688 & 671 & 665 & 671 & 691 & 714 & & & & & \\
\hline 14. New market & PC & $286^{* *}$ & $256^{* *}$ &,- 022 &, $332^{* *}$ &, $353^{* *}$ & $425^{* * 4}$ &, $249^{* *}$ & $248^{* *}$ &,- 021 & $276^{* *}$ &, $152^{* *}$ &,- 015 &, $231^{* *}$ & 1 & & & & \\
\hline structures & Significance &, 000 &, 000 & ,.573 &, 000 &, 000 & , ,000 &, 000 &, 000 &, 589 &, 000 &, 000 &, 700 &, 000 & & & & & \\
\hline & $\mathrm{N}$ & 682 & 674 & 685 & 705 & 700 & 689 & 684 & 690 & 668 & 663 & 671 & 691 & 694 & 716 & & & & \\
\hline 15. Harmfulness of the & PC &, $327^{7 * *}$ &,- 011 &,$- 127^{* *}$ &, $333^{* * *}$ &, $220^{* *}$ & $.222^{* *}$ &, $285^{\text {** }}$ & $310^{* *}$ &,- 055 & $399^{* *}$ &, $437^{* *}$ &,$- 131^{* * 4}$ &, $199^{* * *}$ & $254^{* *}$ & 1 & & & \\
\hline company's activity & Significance & 000 &, 775 & 0,001 & ,000 & 000 & ,000 & 000 & 000 &, 156 & 000 & 000 & ,001 & ,000 & 000 & & & & \\
\hline & $\mathrm{N}$ & \begin{tabular}{|c|}
680 \\
\end{tabular} & 661 & 673 & 700 & 698 & 678 & 676 & 682 & 661 & 662 & 668 & 682 & 683 & 692 & 718 & & & \\
\hline 16. Work safety & PC &, $345^{* *}$ & \begin{tabular}{|l|}
, 061 \\
\end{tabular} &,$- 123^{* 4}$ &, $342^{* *}$ & $332^{* *}$ & $337^{*+4}$ &, $333^{* *}$ & $305^{* *}$ &,- 041 & $390^{* *}$ & $296^{* *}$ & $-148^{*+\infty}$ & $212^{* *}$ & $256^{* *}$ & $536^{* *}$ & 1 & & \\
\hline & Significance &, 000 & \begin{tabular}{|l|}
, 113 \\
\end{tabular} &, 001 &, 000 &, 000 & ,000 &, 000 &, 000 & ,296 &, 000 &, 000 &, 000 &, 000 &, 000 &, 000 & & & \\
\hline & $\mathrm{N}$ & 688 & 664 & 681 & 708 & 703 & 682 & 682 & 689 & 666 & 666 & 670 & 687 & 691 & 696 & 713 & 726 & & \\
\hline 17. Work standards & PC &, $415^{* *}$ &, 009 &,$- 154^{* *}$ &, $418^{* *}$ &, $353^{* *}$ & $232^{* *+}$ &, $345^{* *}$ & $332^{* *}$ &,$- 089^{*}$ &, $367^{* *}$ & $350^{* *}$ &,$- 239^{* *}$ & $211^{* *}$ & $199^{* *}$ & $415^{* *}$ & ,641** & 1 & \\
\hline & Significance & 0 & 820 & 000 & 000 & 000 & (000 & 000 & 000 & 020 & 000 &, 000 & 000 & 000 & 000 &, 000 & 000 & & \\
\hline & $\mathrm{N}$ & \begin{tabular}{ll|}
704 \\
\end{tabular} & 682 & 697 & 727 & 722 & \begin{tabular}{|l|}
699 \\
\end{tabular} & 701 & 706 & 681 & 675 & 681 & 700 & 702 & 710 & 715 & 722 & 747 & \\
\hline 18. Employees & PC &, $454^{* *+}$ & \begin{tabular}{|l|}
, 059 \\
\end{tabular} &,$- 202^{* *}$ &, $405^{* *}$ &, $455^{* *}$ & $324^{* *}$ &, $396^{* *}$ &, $433^{* *}$ &,- 050 &, $444^{* *}$ &, $401^{* *}$ &,$- 218^{* *}$ &, $221^{* *}$ & $263^{* *}$ & $331^{* *}$ &, $357^{* *}$ &, $398^{*+4}$ & 1 \\
\hline & Significance & ,000 & ,123 & ,000 & ,000 &, 000 & ,000 &, 000 & ,000 & ,191 & ,000 & ,000 &, 000 &, 000 & ,000 &, 000 & 0,000 & ,000 & \\
\hline & $\mathrm{N}$ & \begin{tabular}{|l|}
715 \\
\end{tabular} & \begin{tabular}{|l|}
684 \\
\end{tabular} & \begin{tabular}{ll|}
707 \\
\end{tabular} & 734 & 729 & \begin{tabular}{|l|}
702 \\
\end{tabular} & 704 & 710 & 683 & 680 & 685 & 704 & 705 & 711 & 711 & 719 & 738 & 759 \\
\hline
\end{tabular}

Source: own calculation 
Table 3

Model illustrating the impact of investments in innovation on the level of competitiveness

\begin{tabular}{|c|c|c|c|c|c|c|c|c|c|c|c|c|}
\hline & \multicolumn{2}{|c|}{$\begin{array}{l}\text { The rank of an } \\
\text { improved product or } \\
\text { service among other } \\
\text { company products }\end{array}$} & \multicolumn{2}{|c|}{$\begin{array}{c}\text { Revenues due to } \\
\text { crowding out } \\
\text { existing company } \\
\text { products from the } \\
\text { market }\end{array}$} & \multicolumn{2}{|c|}{$\begin{array}{l}\text { Prices of products } \\
\text { and services as a } \\
\text { result of } \\
\text { depreciation costs of } \\
\text { new equipment }\end{array}$} & \multicolumn{2}{|c|}{$\begin{array}{l}\text { The quality of the } \\
\text { improved product or } \\
\text { service in the eyes of } \\
\text { customers }\end{array}$} & \multicolumn{2}{|c|}{$\begin{array}{c}\text { Company's share in } \\
\text { the market }\end{array}$} & \multicolumn{2}{|c|}{ New markets } \\
\hline & Estimate & $\operatorname{Pr}(>|z|)$ & Estimate & $\operatorname{Pr}(>|z|)$ & Estimate & $\operatorname{Pr}(>|z|)$ & Estimate & $\operatorname{Pr}(>|z|)$ & Estimate & $\operatorname{Pr}(>|z|)$ & Estimate & $\operatorname{Pr}(>|z|)$ \\
\hline Size & 0.043501 & 0.6995 & 0.31141 & 0.08653 & -0.20723 & 0.074512 & 0.21202 & $\begin{array}{c}0.044156 \\
*\end{array}$ & 0.28742 & $\begin{array}{c}0.005472 \\
* *\end{array}$ & 0.20308 & 0.0693 \\
\hline \multicolumn{13}{|l|}{ Sector } \\
\hline Agriculture & -1.444756 & $0.0424 *$ & -0.0601 & 0.93947 & 0.14666 & 0.796166 & -0.50885 & 0.300925 & -0.33367 & 0.47699 & -0.39280 & 0.3974 \\
\hline Industry & 0.478154 & $0.0250 *$ & -0.02341 & 0.94357 & -0.02522 & 0.911782 & -0.05229 & 0.796887 & 0.69923 & $\begin{array}{c}0.000483 \\
* * *\end{array}$ & 0.43673 & $0.0366 *$ \\
\hline Construction & -0.000343 & 0.9992 & -0.54795 & 0.27905 & -0.31604 & 0.372845 & -0.50314 & 0.13466 & 0.23166 & 0.482117 & -0.13748 & 0.7019 \\
\hline Trade & 0.167083 & 0.6594 & -1.44968 & $\begin{array}{c}0.00488 \\
* *\end{array}$ & -0.98549 & $\begin{array}{c}0.006331 \\
* *\end{array}$ & 0.37010 & 0.29093 & 0.82448 & $\begin{array}{c}0.022296 \\
*\end{array}$ & -0.22757 & 0.5565 \\
\hline Transport & 0.325077 & 0.5109 & 0.86980 & 0.41130 & -0.49298 & 0.263338 & -0.14423 & 0.74195 & 0.06017 & 0.880118 & 0.34735 & 0.4064 \\
\hline Social affairs & 0.309196 & 0.6392 & -0.09131 & 0.93448 & -0.04391 & 0.952153 & -0.06485 & 0.91348 & -0.61257 & 0.335069 & -0.58459 & 0.4087 \\
\hline Services & NA & NA & $\mathrm{NA}$ & $\mathrm{NA}$ & NA & NA & NA & NA & NA & NA & NA & NA \\
\hline \multicolumn{13}{|l|}{$\begin{array}{l}\text { Type of } \\
\text { investment }\end{array}$} \\
\hline $\begin{array}{l}\text { Expenditures } \\
\text { on machinery } \\
\text { and equipment }\end{array}$ & 0.981064 & $\begin{array}{l}2.86 \mathrm{e}-07 \\
* * *\end{array}$ & -0.43226 & 0.15367 & -0.68566 & $\begin{array}{l}0.000944 \\
* * *\end{array}$ & 0.72508 & $\begin{array}{c}8.96 \mathrm{e}-05 \\
* * *\end{array}$ & 0.49565 & $\begin{array}{c}0.006072 \\
* *\end{array}$ & 0.10243 & 0.5927 \\
\hline $\begin{array}{l}\text { Expenditures } \\
\text { on ICT }\end{array}$ & -0.090811 & 0.6338 & -0.33865 & 0.26107 & -0.07418 & 0.706443 & -0.07362 & 0.679701 & 0.03305 & 0.847751 & 0.11039 & 0.5489 \\
\hline $\begin{array}{l}\text { expenditure on } \\
\text { intellectual } \\
\text { property } \\
\text { protection } \\
\end{array}$ & 0.375826 & 0.0979 . & 0.32827 & 0.38911 & -0.26966 & 0.235349 & 0.51237 & $\begin{array}{c}0.016444 \\
*\end{array}$ & 0.31439 & 0.142460 & 0.31203 & 0.1752 \\
\hline $\begin{array}{l}\text { Expenditure on } \\
\text { training }\end{array}$ & 0.275806 & 0.1593 & -0.11395 & 0.71333 & 0.06907 & 0.738821 & 0.17249 & 0.351046 & 0.42669 & $\begin{array}{c}0.021511 \\
* \\
\end{array}$ & 0.24806 & 0.2229 \\
\hline $\begin{array}{l}\text { Expenditures } \\
\text { on marketing } \\
\text { activities }\end{array}$ & 0.840005 & $\begin{array}{c}3.26 \mathrm{e}-05 \\
* * *\end{array}$ & -0.3253 & 0.29382 & 0.14069 & 0.510175 & 0.70669 & $\begin{array}{l}0.000237 \\
* * *\end{array}$ & 0.75535 & $\begin{array}{l}0.000110 \\
* * *\end{array}$ & 0.97777 & $\begin{array}{c}4.31 \mathrm{e}-06 \\
* * *\end{array}$ \\
\hline $\begin{array}{l}\text { Expenditures } \\
\text { on the } \\
\text { implementation } \\
\text { of new } \\
\text { solutions } \\
\end{array}$ & 0.25891 & 0.4222 & -0.55123 & 0.23611 & 0.36034 & 0.269223 & 0.29825 & 0.314028 & -0.02697 & 0.926123 & 0.23617 & 0.4425 \\
\hline $\begin{array}{l}\text { Company type } \\
\text { (innovative / } \\
\text { non- } \\
\text { innovative) } \\
\end{array}$ & 0.919072 & $\begin{array}{c}<2 \mathrm{e}-16 \\
* * *\end{array}$ & 0.04376 & 0.75984 & -0.34443 & $\begin{array}{l}0.000193 \\
* * *\end{array}$ & 0.70342 & $\begin{array}{l}1.51 \mathrm{e}-14 \\
* * *\end{array}$ & 0.53274 & $\begin{array}{c}1.82 \mathrm{e}-09 \\
* * *\end{array}$ & 0.39453 & $\begin{array}{l}2.94 \mathrm{e}-05 \\
* * *\end{array}$ \\
\hline
\end{tabular}


Table 3 (continued)

Model illustrating the impact of investments in innovation on the level of competitiveness

\begin{tabular}{|c|c|c|c|c|c|c|c|c|c|c|c|c|}
\hline & \multicolumn{2}{|c|}{$\begin{array}{c}\text { Production } \\
\text { flexibility }\end{array}$} & \multicolumn{2}{|c|}{$\begin{array}{c}\text { Production } \\
\text { efficiency }\end{array}$} & \multicolumn{2}{|c|}{$\begin{array}{c}\text { Downtime and } \\
\text { failures }\end{array}$} & \multicolumn{2}{|c|}{ Labor costs } & \multicolumn{2}{|c|}{$\begin{array}{c}\text { Amount of materials } \\
\text { and energy }\end{array}$} & \multicolumn{2}{|c|}{ Operating costs } \\
\hline & Estimate & $\operatorname{Pr}(>|z|)$ & Estimate & $\operatorname{Pr}(>|z|)$ & Estimate & $\operatorname{Pr}(>|z|)$ & Estimate & $\operatorname{Pr}(>|z|)$ & Estimate & $\operatorname{Pr}(>|z|)$ & Estimate & $\operatorname{Pr}(>|z|)$ \\
\hline Size & 0.137656 & 0.254732 & 0.19129 & 0.1088 & NA & NA & -0.043338 & 0.754169 & 0.04604 & 0.76215 & -0.23327 & 0.05813 \\
\hline \multicolumn{13}{|l|}{ Sector } \\
\hline Agriculture & -0.915207 & 0.202325 & -0.38106 & 0.58227 & NA & NA & 0.387690 & 0.635531 & -0.27112 & 0.801731 & -0.98548 & 0.07117 . \\
\hline Industry & 0.829186 & $\begin{array}{c}0.000703 \\
* * *\end{array}$ & 0.71854 & $\begin{array}{c}0.00332 \\
* *\end{array}$ & NA & $\mathrm{NA}$ & 1.020686 & $\begin{array}{c}0.000962 \\
* * *\end{array}$ & 0.46645 & 0.165825 & -0.35458 & 0.18129 \\
\hline Construction & -0.149172 & 0.724392 & -0.31317 & 0.46333 & NA & NA & 0.912992 & $\begin{array}{c}0.041255 \\
*\end{array}$ & 0.42235 & 0.405018 & -1.09653 & $\begin{array}{c}0.00423 \\
* *\end{array}$ \\
\hline Trade & 0.364844 & 0.391304 & 0.50954 & 0.19958 & NA & $\mathrm{NA}$ & 1.360093 & $\begin{array}{c}0.002923 \\
* *\end{array}$ & 1.22359 & $\begin{array}{c}0.010503 \\
*\end{array}$ & -1.79815 & $\begin{array}{c}1.55 \mathrm{e}-06 \\
* * *\end{array}$ \\
\hline Transport & -0.447392 & 0.468646 & -0.78255 & 0.24581 & NA & NA & 0.101018 & 0.877459 & 0.66050 & 0.295927 & -0.22858 & 0.67702 \\
\hline Social affairs & -0.045632 & 0.958396 & 0.37629 & 0.62046 & NA & $\mathrm{NA}$ & -0.005629 & 0.995472 & 1.07464 & 0.243797 & -1.06435 & 0.19221 \\
\hline Services & NA & NA & NA & NA & NA & NA & NA & NA & NA & NA & NA & NA \\
\hline \multicolumn{13}{|l|}{$\begin{array}{l}\text { Type of } \\
\text { investment }\end{array}$} \\
\hline $\begin{array}{l}\text { Expenditures } \\
\text { on machinery } \\
\text { and equipment }\end{array}$ & 1.075819 & $\begin{array}{l}2.31 \mathrm{e}-06 \\
* * *\end{array}$ & 1.16881 & $\begin{array}{l}3.00 \mathrm{e}-07 \\
* * *\end{array}$ & NA & NA & 1.380924 & $\begin{array}{c}9.31 \mathrm{e}-07 \\
* * *\end{array}$ & 0.81018 & $\begin{array}{c}0.008235 \\
* *\end{array}$ & -0.97307 & $\begin{array}{c}3.78 \mathrm{e}-05 \\
* * *\end{array}$ \\
\hline $\begin{array}{l}\text { Expenditures } \\
\text { on ICT }\end{array}$ & 0.003983 & 0.984592 & -0.06049 & 0.76932 & NA & NA & -0.161419 & 0.486869 & -0.05886 & 0.825215 & 0.01503 & 0.94458 \\
\hline $\begin{array}{l}\text { Expenditure on } \\
\text { intellectual } \\
\text { property } \\
\text { protection }\end{array}$ & 0.099997 & 0.672814 & 0.26873 & 0.25356 & NA & NA & 0.668900 & $\begin{array}{c}0.008272 \\
* *\end{array}$ & 0.6082 & $\begin{array}{c}0.034936 \\
*\end{array}$ & -0.39544 & 0.09093 . \\
\hline $\begin{array}{l}\text { Expenditure on } \\
\text { training }\end{array}$ & 0.288605 & 0.181137 & 0.20297 & 0.34454 & NA & $\mathrm{NA}$ & 0.281413 & 0.243714 & 0.35674 & 0.192451 & -0.19278 & 0.38162 \\
\hline $\begin{array}{l}\text { Expenditures } \\
\text { on marketing } \\
\text { activities }\end{array}$ & 0.798799 & $\begin{array}{c}0.000214 \\
* * *\end{array}$ & 0.8892 & $\begin{array}{c}2.83 \mathrm{e}-05 \\
* * *\end{array}$ & NA & NA & 0.166182 & 0.500989 & 0.52295 & $\begin{array}{c}0.051754 \\
.\end{array}$ & -0.19170 & 0.39209 \\
\hline $\begin{array}{l}\text { Expenditures } \\
\text { on the } \\
\text { implementation } \\
\text { of new } \\
\text { solutions }\end{array}$ & -0.733465 & $\begin{array}{c}0.021713 \\
*\end{array}$ & -0.5623 & 0.07441 . & $\mathrm{NA}$ & $\mathrm{NA}$ & 0.274394 & 0.409863 & 0.47179 & 0.182599 & 0.35776 & 0.29418 \\
\hline $\begin{array}{l}\text { Company type } \\
\text { (innovative / } \\
\text { non- } \\
\text { innovative) }\end{array}$ & 0.509864 & $\begin{array}{c}2.86 \mathrm{e}-07 \\
* * *\end{array}$ & 0.60183 & $\begin{array}{c}1.03 \mathrm{e}-09 \\
* * *\end{array}$ & NA & $\mathrm{NA}$ & 0.374578 & $\begin{array}{c}0.000795 \\
* * *\end{array}$ & 0.43628 & $\begin{array}{l}0.000344 \\
* * *\end{array}$ & -0.31410 & $\begin{array}{c}0.00146 \\
* *\end{array}$ \\
\hline
\end{tabular}


Table 3 (continued)

Model illustrating the impact of investments in innovation on the level of competitiveness

\begin{tabular}{|c|c|c|c|c|c|c|c|c|c|c|c|c|}
\hline & \multicolumn{2}{|c|}{ Sources of supply } & \multicolumn{2}{|c|}{$\begin{array}{l}\text { New market } \\
\text { structures }\end{array}$} & \multicolumn{2}{|c|}{$\begin{array}{l}\text { Harmfulness of the } \\
\text { company's activity }\end{array}$} & \multicolumn{2}{|c|}{ Work safety } & \multicolumn{2}{|c|}{ Work standards } & \multicolumn{2}{|c|}{ Employees } \\
\hline & Estimate & $\operatorname{Pr}(>|z|)$ & Estimate & $\operatorname{Pr}(>|z|)$ & Estimate & $\operatorname{Pr}(>|z|)$ & Estimate & $\operatorname{Pr}(>|z|)$ & Estimate & $\operatorname{Pr}(>|z|)$ & Estimate & $\operatorname{Pr}(>|z|)$ \\
\hline Size & 0.13755 & 0.31298 & 0.364773 & $0.015314 *$ & 0.05421 & 0.70951 & 0.28324 & $0.01425 *$ & 0.38718 & $\begin{array}{c}0.00032 \\
* * *\end{array}$ & 0.435783 & $\begin{array}{c}0.000202 \\
* * *\end{array}$ \\
\hline \multicolumn{13}{|l|}{ Sector } \\
\hline Agriculture & -0.14558 & 0.81186 & 0.039422 & 0.949775 & -0.36241 & 0.68425 & 0.28303 & 0.56537 & 0.42041 & 0.35877 & 0.143068 & 0.786766 \\
\hline Industry & -0.07739 & 0.76903 & 0.196794 & 0.486555 & 0.72191 & $0.02663 *$ & 0.21563 & 0.33957 & 0.11343 & 0.59131 & 0.449348 & 0.052311 . \\
\hline Construction & -0.48934 & 0.27019 & 0.044979 & 0.922099 & 0.25158 & 0.63150 & -0.17418 & 0.64881 & -0.24463 & 0.48258 & 0.632840 & 0.072159 . \\
\hline Trade & -0.41320 & 0.39381 & -0.223965 & 0.671636 & 1.16140 & $0.01609 *$ & -0.05452 & 0.89431 & 0.75965 & $0.02471 *$ & 0.339135 & 0.384472 \\
\hline Transport & 0.10740 & 0.84672 & -0.769255 & 0.166283 & 0.30930 & 0.63830 & 0.16400 & 0.74125 & 0.41450 & 0.33271 & 0.898241 & $0.049322 *$ \\
\hline Social affairs & 0.06706 & 0.94143 & -0.086544 & 0.912658 & -1.71422 & 0.15047 & 0.77825 & 0.24304 & 0.69614 & 0.29936 & 0.900044 & 0.128053 \\
\hline Services & NA & NA & NA & NA & NA & $\mathrm{NA}$ & NA & NA & NA & NA & NA & NA \\
\hline \multicolumn{13}{|l|}{ Type of investment } \\
\hline $\begin{array}{l}\text { Expenditures on } \\
\text { machinery and } \\
\text { equipment }\end{array}$ & 0.75934 & $0.00289 * *$ & -0.159550 & 0.530181 & 0.81639 & $0.00803 * *$ & 0.40208 & 0.05287 . & 0.50889 & $0.00707 * *$ & 0.618250 & $\begin{array}{c}0.003075 \\
* *\end{array}$ \\
\hline Expenditures on ICT & -0.05023 & 0.82870 & 0.176344 & 0.480925 & -0.39057 & 0.13091 & -0.22579 & 0.25117 & -0.18602 & 0.30673 & 0.003668 & 0.985163 \\
\hline $\begin{array}{l}\text { Expenditure on } \\
\text { intellectual property } \\
\text { protection }\end{array}$ & 0.58843 & $0.02682 *$ & 1.082745 & $\begin{array}{c}0.000282 \\
* * *\end{array}$ & 0.88036 & $0.00241 * *$ & 0.61927 & $0.00782 * *$ & 0.44261 & $0.03975 *$ & 0.577843 & $0.010368 *$ \\
\hline Expenditure on training & -0.31777 & 0.19596 & -0.007742 & 0.976566 & 0.13335 & 0.63120 & 0.13532 & 0.51750 & 0.21322 & 0.26847 & 0.917336 & $\begin{array}{c}9.03 \mathrm{e}-06 \\
* * *\end{array}$ \\
\hline \begin{tabular}{|l} 
Expenditures on \\
marketing activities
\end{tabular} & 0.62556 & $0.01199 *$ & 0.542585 & 0.053065 & 0.35823 & 0.18369 & 0.13123 & 0.54355 & 0.22932 & 0.24749 & 0.247597 & 0.240624 \\
\hline $\begin{array}{l}\text { Expenditures on the } \\
\text { implementation of new } \\
\text { solutions }\end{array}$ & 0.07416 & 0.82739 & 1.091468 & $\begin{array}{c}0.003590 \\
* *\end{array}$ & 0.74112 & $0.03548 *$ & 0.51143 & 0.09510 . & -0.18077 & 0.56293 & -0.515413 & 0.107275 \\
\hline $\begin{array}{l}\text { Company type } \\
\text { (innovative / non- } \\
\text { innovative) }\end{array}$ & 0.45790 & $\begin{array}{c}1.89 \mathrm{e}-05 \\
* * *\end{array}$ & 0.269430 & $0.024105 *$ & 0.37354 & $0.00131 * *$ & 0.26676 & $0.00514 * *$ & 0.45298 & $\begin{array}{c}4.18 \mathrm{e}-07 \\
* * *\end{array}$ & 0.466567 & $\begin{array}{l}5.33 \mathrm{e}-07 \\
* * *\end{array}$ \\
\hline
\end{tabular}

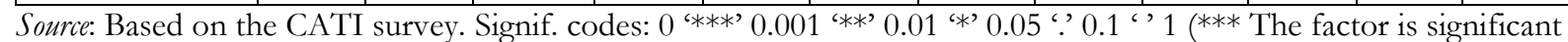
at the significance level of $0 .{ }^{* *}$ The factor is significant at the significance level of 0.001 . $*$ The factor is significant at the significance level of 0.01). 
Table 4

The marginal effect of changing investment in innovation on the level of competitiveness of SMEs

\begin{tabular}{|c|c|c|c|c|c|c|c|c|c|c|c|c|}
\hline & \multicolumn{2}{|c|}{$\begin{array}{l}\text { The rank of an } \\
\text { improved } \\
\text { product or } \\
\text { service among } \\
\text { other company } \\
\text { products }\end{array}$} & \multicolumn{2}{|c|}{$\begin{array}{l}\text { Revenues due } \\
\text { to crowding } \\
\text { out existing } \\
\text { company } \\
\text { products from } \\
\text { the market }\end{array}$} & \multicolumn{2}{|c|}{$\begin{array}{c}\text { Prices of } \\
\text { products and } \\
\text { services as a } \\
\text { result of } \\
\text { depreciation } \\
\text { costs of new } \\
\text { equipment }\end{array}$} & \multicolumn{2}{|c|}{$\begin{array}{l}\text { The quality of } \\
\text { the improved } \\
\text { product or } \\
\text { service in the } \\
\text { eyes of } \\
\text { customers }\end{array}$} & \multicolumn{2}{|c|}{$\begin{array}{l}\text { Company's } \\
\text { share in the } \\
\text { market }\end{array}$} & \multicolumn{2}{|c|}{ New markets } \\
\hline Size & 1.04 & $4 \%$ & 1.37 & $37 \%$ & 0.81 & $-19 \%$ & 1.24 & $24 \%$ & 1.33 & $33 \%$ & 1.23 & $23 \%$ \\
\hline \multicolumn{13}{|l|}{ Sector } \\
\hline Agriculture & 0.24 & $-76 \%$ & 0.94 & $-6 \%$ & 1.16 & $16 \%$ & 0.6 & $-40 \%$ & 0.72 & $-28 \%$ & 0.68 & $-32 \%$ \\
\hline Industry & 1.61 & $61 \%$ & 0.98 & $-2 \%$ & 0.98 & $-2 \%$ & 0.95 & $-5 \%$ & 2.01 & $101 \%$ & 1.55 & $55 \%$ \\
\hline Construction & 1.00 & $0 \%$ & 0.58 & $-42 \%$ & 0.73 & $-27 \%$ & 0.6 & $-40 \%$ & 1.26 & $26 \%$ & 0.87 & $-13 \%$ \\
\hline Trade & 1.18 & $18 \%$ & 0.23 & $-77 \%$ & 0.37 & $-63 \%$ & 1.45 & $45 \%$ & 2.28 & $128 \%$ & 0.8 & $-20 \%$ \\
\hline Transport & 1.38 & $38 \%$ & 2.39 & $139 \%$ & 0.61 & $-39 \%$ & 0.87 & $-13 \%$ & 1.06 & $6 \%$ & 1.42 & $42 \%$ \\
\hline Social affairs & 1.36 & $36 \%$ & 0.91 & $-9 \%$ & 0.96 & $-4 \%$ & 0.94 & $-6 \%$ & 0.54 & $-46 \%$ & 0.56 & $-44 \%$ \\
\hline Services & NA & $\mathrm{NA}$ & NA & NA & NA & NA & NA & NA & NA & NA & NA & NA \\
\hline \multicolumn{13}{|l|}{$\begin{array}{l}\text { Type of } \\
\text { investment }\end{array}$} \\
\hline $\begin{array}{l}\text { Expenditures on } \\
\text { machinery and } \\
\text { equipment }\end{array}$ & 2.67 & $167 \%$ & 0.65 & $-35 \%$ & 0.5 & $-50 \%$ & 2.06 & $106 \%$ & 1.64 & $64 \%$ & 1.11 & $11 \%$ \\
\hline $\begin{array}{l}\text { Expenditures on } \\
\text { ICT }\end{array}$ & 0.91 & $-9 \%$ & 0.71 & $-29 \%$ & 0.93 & $-7 \%$ & 0.93 & $-7 \%$ & 1.03 & $3 \%$ & 1.12 & $12 \%$ \\
\hline $\begin{array}{l}\text { expenditure on } \\
\text { intellectual } \\
\text { property } \\
\text { protection }\end{array}$ & 1.46 & $46 \%$ & 1.39 & $39 \%$ & 0.76 & $-24 \%$ & 1.67 & $67 \%$ & 1.37 & $37 \%$ & 1.37 & $37 \%$ \\
\hline $\begin{array}{l}\text { Expenditure on } \\
\text { training }\end{array}$ & 1.32 & $32 \%$ & 0.89 & $-11 \%$ & 1.07 & $7 \%$ & 1.19 & $19 \%$ & 1.53 & $53 \%$ & 1.28 & $28 \%$ \\
\hline $\begin{array}{l}\text { Expenditures on } \\
\text { marketing } \\
\text { activities }\end{array}$ & 2.32 & $132 \%$ & 0.72 & $-28 \%$ & 1.15 & $15 \%$ & 2.03 & $103 \%$ & 2.13 & $113 \%$ & 2.66 & $166 \%$ \\
\hline $\begin{array}{l}\text { Expenditures on } \\
\text { the } \\
\text { implementation of } \\
\text { new solutions }\end{array}$ & 1.30 & $30 \%$ & 0.58 & $-42 \%$ & 1.43 & $43 \%$ & 1.35 & $35 \%$ & 0.97 & $-3 \%$ & 1.27 & $27 \%$ \\
\hline $\begin{array}{l}\text { Company type } \\
\text { (innovative / } \\
\text { non-innovative) }\end{array}$ & 2.51 & $151 \%$ & 1.04 & $4 \%$ & 0.71 & $-29 \%$ & 2.02 & $102 \%$ & 1.7 & $70 \%$ & 1.48 & $48 \%$ \\
\hline
\end{tabular}


Table 4 (continued)

The marginal effect of changing investment in innovation on the level of competitiveness of SMEs

\begin{tabular}{|c|c|c|c|c|c|c|c|c|c|c|c|c|}
\hline & \multicolumn{2}{|c|}{$\begin{array}{l}\text { Production } \\
\text { flexibility }\end{array}$} & \multicolumn{2}{|c|}{$\begin{array}{l}\text { Production } \\
\text { efficiency }\end{array}$} & \multicolumn{2}{|c|}{$\begin{array}{l}\text { Downtime and } \\
\text { failures }\end{array}$} & \multicolumn{2}{|c|}{ Labor costs } & \multicolumn{2}{|c|}{$\begin{array}{c}\text { Amount of } \\
\text { materials and } \\
\text { energy }\end{array}$} & \multicolumn{2}{|c|}{$\begin{array}{l}\text { Operating } \\
\text { costs }\end{array}$} \\
\hline Size & 1.15 & $15 \%$ & 1.21 & $21 \%$ & $\mathrm{NA}$ & NA & 0.96 & $-4 \%$ & 1.05 & $5 \%$ & 0.79 & $-21 \%$ \\
\hline \multicolumn{13}{|l|}{ Sector } \\
\hline Agriculture & 0.40 & $-60 \%$ & 0.68 & $-32 \%$ & $\mathrm{NA}$ & NA & 1.47 & $47 \%$ & 0.76 & $-24 \%$ & 0.37 & $-63 \%$ \\
\hline Industry & 2.29 & $129 \%$ & 2.05 & $105 \%$ & $\mathrm{NA}$ & NA & 2.78 & $178 \%$ & 1.59 & $59 \%$ & 0.7 & $-30 \%$ \\
\hline Construction & 0.86 & $-14 \%$ & 0.73 & $-27 \%$ & $\mathrm{NA}$ & NA & 2.49 & $149 \%$ & 1.53 & $53 \%$ & 0.33 & $-67 \%$ \\
\hline Trade & 1.44 & $44 \%$ & 1.66 & $66 \%$ & $\mathrm{NA}$ & NA & 3.9 & $290 \%$ & 3.4 & $240 \%$ & 0.17 & $-83 \%$ \\
\hline Transport & 0.64 & $-36 \%$ & 0.46 & $-54 \%$ & NA & NA & 1.11 & $11 \%$ & 1.94 & $94 \%$ & 0.8 & $-20 \%$ \\
\hline Social affairs & 0.96 & $-4 \%$ & 1.46 & $46 \%$ & $\mathrm{NA}$ & NA & 0.99 & $-1 \%$ & 2.93 & $193 \%$ & 0.34 & $-66 \%$ \\
\hline Services & NA & NA & $\mathrm{NA}$ & NA & $\mathrm{NA}$ & NA & $\mathrm{NA}$ & NA & NA & NA & NA & $\mathrm{NA}$ \\
\hline \multicolumn{13}{|l|}{$\begin{array}{l}\text { Type of } \\
\text { investment }\end{array}$} \\
\hline $\begin{array}{l}\text { Expenditures on } \\
\text { machinery and } \\
\text { equipment }\end{array}$ & 2.93 & $193 \%$ & 3.22 & $222 \%$ & NA & NA & 3.98 & $298 \%$ & 2.25 & $125 \%$ & 0.38 & $-62 \%$ \\
\hline $\begin{array}{l}\text { Expenditures on } \\
\text { ICT }\end{array}$ & 1 & $0 \%$ & 0.94 & $-6 \%$ & NA & NA & 0.85 & $-15 \%$ & 0.94 & $-6 \%$ & 1.02 & $2 \%$ \\
\hline $\begin{array}{l}\text { expenditure on } \\
\text { intellectual } \\
\text { property } \\
\text { protection }\end{array}$ & 1.11 & $11 \%$ & 1.31 & $31 \%$ & $\mathrm{NA}$ & NA & 1.95 & $95 \%$ & 1.84 & $84 \%$ & 0.67 & $-33 \%$ \\
\hline $\begin{array}{l}\text { Expenditure on } \\
\text { training }\end{array}$ & 1.33 & $33 \%$ & 1.23 & $23 \%$ & $\mathrm{NA}$ & NA & 1.33 & $33 \%$ & 1.43 & $43 \%$ & 0.82 & $-18 \%$ \\
\hline $\begin{array}{l}\text { Expenditures on } \\
\text { marketing } \\
\text { activities }\end{array}$ & 2.22 & $122 \%$ & 2.43 & $143 \%$ & NA & NA & 1.18 & $18 \%$ & 1.69 & $69 \%$ & 0.83 & $-17 \%$ \\
\hline $\begin{array}{l}\text { Expenditures on } \\
\text { the } \\
\text { implementation of } \\
\text { new solutions }\end{array}$ & 0.48 & $-52 \%$ & 0.57 & $-43 \%$ & $\mathrm{NA}$ & NA & 1.32 & $32 \%$ & 1.6 & $60 \%$ & 1.43 & $43 \%$ \\
\hline $\begin{array}{l}\text { Company type } \\
\text { (innovative / } \\
\text { non-innovative) }\end{array}$ & 1.67 & $67 \%$ & 1.83 & $83 \%$ & NA & NA & 1.45 & $45 \%$ & 1.55 & $55 \%$ & 0.73 & $-27 \%$ \\
\hline
\end{tabular}


Table 4 (continued)

The marginal effect of changing investment in innovation on the level of competitiveness of SMEs

\begin{tabular}{|c|c|c|c|c|c|c|c|c|c|c|c|c|}
\hline & \multicolumn{2}{|c|}{$\begin{array}{c}\text { Sources of } \\
\text { supply }\end{array}$} & \multicolumn{2}{|c|}{$\begin{array}{l}\text { New market } \\
\text { structures }\end{array}$} & \multicolumn{2}{|c|}{$\begin{array}{l}\text { Harmfulness } \\
\text { of the } \\
\text { company's } \\
\text { activity }\end{array}$} & \multicolumn{2}{|c|}{ Work safety } & \multicolumn{2}{|c|}{$\begin{array}{c}\text { Work } \\
\text { standards }\end{array}$} & \multicolumn{2}{|c|}{ Employees } \\
\hline Size & 1.15 & $15 \%$ & 1.44 & $44 \%$ & 1.06 & $6 \%$ & 1.33 & $33 \%$ & 1.47 & $47 \%$ & 1.55 & $55 \%$ \\
\hline \multicolumn{13}{|l|}{ Sector } \\
\hline Agriculture & 0.86 & $-14 \%$ & 1.04 & $4 \%$ & 0.7 & $-30 \%$ & 1.33 & $33 \%$ & 1.52 & $52 \%$ & 1.15 & $15 \%$ \\
\hline Industry & 0.93 & $-7 \%$ & 1.22 & $22 \%$ & 2.06 & $106 \%$ & 1.24 & $24 \%$ & 1.12 & $12 \%$ & 1.57 & $57 \%$ \\
\hline Construction & 0.61 & $-39 \%$ & 1.05 & $5 \%$ & 1.29 & $29 \%$ & 0.84 & $-16 \%$ & 0.78 & $-22 \%$ & 1.88 & $88 \%$ \\
\hline Trade & 0.66 & $-34 \%$ & 0.8 & $-20 \%$ & 3.19 & $219 \%$ & 0.95 & $-5 \%$ & 2.14 & $114 \%$ & 1.4 & $40 \%$ \\
\hline Transport & 1.11 & $11 \%$ & 0.46 & $-54 \%$ & 1.36 & $36 \%$ & 1.18 & $18 \%$ & 1.51 & $51 \%$ & 2.46 & $146 \%$ \\
\hline Social affairs & 1.07 & $7 \%$ & 0.92 & $-8 \%$ & 0.18 & $-82 \%$ & 2.18 & $118 \%$ & 2.01 & $101 \%$ & 2.46 & $146 \%$ \\
\hline Services & NA & NA & NA & NA & NA & NA & NA & NA & NA & NA & NA & NA \\
\hline \multicolumn{13}{|l|}{$\begin{array}{l}\text { Type of } \\
\text { investment }\end{array}$} \\
\hline $\begin{array}{l}\text { Expenditures on } \\
\text { machinery and } \\
\text { equipment }\end{array}$ & 2.14 & $114 \%$ & 0.85 & $-15 \%$ & 2.26 & $126 \%$ & 1.49 & $49 \%$ & 1.66 & $66 \%$ & 1.86 & $86 \%$ \\
\hline $\begin{array}{l}\text { Expenditures on } \\
\text { ICT }\end{array}$ & 0.95 & $-5 \%$ & 1.19 & $19 \%$ & 0.68 & $-32 \%$ & 0.8 & $-20 \%$ & 0.83 & $-17 \%$ & 1 & $0 \%$ \\
\hline $\begin{array}{l}\text { expenditure on } \\
\text { intellectual } \\
\text { property } \\
\text { protection }\end{array}$ & 1.8 & $80 \%$ & 2.95 & $195 \%$ & 2.41 & $141 \%$ & 1.86 & $86 \%$ & 1.56 & $56 \%$ & 1.78 & $78 \%$ \\
\hline $\begin{array}{l}\text { Expenditure on } \\
\text { training }\end{array}$ & 0.73 & $-27 \%$ & 0.99 & $-1 \%$ & 1.14 & $14 \%$ & 1.14 & $14 \%$ & 1.24 & $24 \%$ & 2.5 & $150 \%$ \\
\hline $\begin{array}{l}\text { Expenditures on } \\
\text { marketing } \\
\text { activities }\end{array}$ & 1.87 & $87 \%$ & 1.72 & $72 \%$ & 1.43 & $43 \%$ & 1.14 & $14 \%$ & 1.26 & $26 \%$ & 1.28 & $28 \%$ \\
\hline $\begin{array}{l}\text { Expenditures on } \\
\text { the } \\
\text { implementation of } \\
\text { new solutions }\end{array}$ & 1.08 & $8 \%$ & 2.98 & $198 \%$ & 2.1 & $110 \%$ & 1.67 & $67 \%$ & 0.83 & $-17 \%$ & 0.6 & $-40 \%$ \\
\hline $\begin{array}{l}\text { Company type } \\
\text { (innovative / } \\
\text { non-innovative) }\end{array}$ & 1.58 & $58 \%$ & 1.31 & $31 \%$ & 1.45 & $45 \%$ & 1.31 & $31 \%$ & 1.57 & $57 \%$ & 1.59 & $59 \%$ \\
\hline
\end{tabular}

Source: Based on the CATI survey.

The factor is significant at the significance level of 0 (positive impact).

The factor is significant at the significance level of 0,001 (positive impact).

The factor is significant at the significance level of 0,01 (positive impact).
The factor is significant at the significance level of 0 (negative impact).

The factor is significant at the significance level of 0,001 (negative impact).

The factor is significant at the significance level of 0,01 (negative impact). 
Description of Variables

\begin{tabular}{|c|c|c|c|}
\hline Variable & Description & Measurement & Source \\
\hline \multicolumn{4}{|c|}{ Dependent variable } \\
\hline $\begin{array}{l}\text { A measure of } \\
\text { competitiveness } \\
\text { (the effects of } \\
\text { investment in } \\
\text { innovation) } \\
\text { occurring in the } \\
\text { enterprise under } \\
\text { the influence of } \\
\text { investment in } \\
\text { innovation }\end{array}$ & $\begin{array}{l}\text { Rank of an improved product or service } \\
\text { among other products } \\
\text { Revenues from the market due to } \\
\text { support of existing enterprise products } \\
\text { Prices of products and services as a } \\
\text { result of the depreciation costs of new } \\
\text { equipment } \\
\text { Quality of improved product or service } \\
\text { in the eyes of customers } \\
\text { Company market share } \\
\text { New markets } \\
\text { Production flexibility } \\
\text { Production efficiency } \\
\text { Downtime and breakdowns } \\
\text { Labor costs } \\
\text { Amount of materials and energy } \\
\text { Operating costs } \\
\text { Sources of supply } \\
\text { New market structures } \\
\text { Harmful activity enterprises } \\
\text { Work safety } \\
\text { Labor standards } \\
\text { Employees }\end{array}$ & $\begin{array}{l}\text { These variables are } \\
\text { classified from "-3" } \\
\text { (largest negative) to } \\
\text { "3" (largest } \\
\text { positive) and are } \\
\text { rescaled from } 0 \\
\text { (negative) to } 1 \\
\text { (positive). } \\
\text { *However, the } \\
\text { description of the } \\
\text { value may vary } \\
\text { depending on the } \\
\text { feature, e.g. at a } \\
\text { cost of "-3" means } \\
\text { a big increase, and } \\
\text { at a quality of "-3" } \\
\text { means a big } \\
\text { decrease. }\end{array}$ & $\begin{array}{l}\text { [Oslo Manual, } \\
\text { 2005:35; Leal } \\
\text { Filho \& Weresa, } \\
\text { 2007; Report } \\
\text { "Badanie } \\
\text { wpływu...", } \\
\text { 2009] }\end{array}$ \\
\hline \multicolumn{4}{|c|}{ Independent variable } \\
\hline The company size & $\begin{array}{l}\text { Micro enterprises } \\
\text { Small enterprises } \\
\text { Medium enterprises }\end{array}$ & $\begin{array}{l}1-\text { micro } \\
2-\text { small } \\
3 \text { - medium }\end{array}$ & $\begin{array}{l}\text { Statistics Poland } \\
\text { (Polish: Główny } \\
\text { Urząd } \\
\text { Statystyczny, } \\
\text { popularly called } \\
\text { GUS - } \\
\text { stat.gov.pl) }\end{array}$ \\
\hline $\begin{array}{l}\text { The enterprise } \\
\text { sector }\end{array}$ & $\begin{array}{l}\text { Agriculture } \\
\text { Industry } \\
\text { Construction } \\
\text { Trade } \\
\text { Transport } \\
\text { Social affairs } \\
\text { Services }\end{array}$ & $\begin{array}{l}1 \text { - agriculture } \\
2 \text { - industry } \\
3 \text { - construction } \\
4 \text { - trade } \\
5 \text { - transport } \\
6 \text { - social affairs } \\
7 \text { - services }\end{array}$ & $\begin{array}{l}\text { Statistics Poland } \\
\text { (Polish: Glówny } \\
\text { Urząd } \\
\text { Statystyczny, } \\
\text { popularly called } \\
\text { GUS - } \\
\text { stat.gov.pl) }\end{array}$ \\
\hline
\end{tabular}




\begin{tabular}{|c|c|c|c|}
\hline $\begin{array}{l}\text { The type of } \\
\text { investments in } \\
\text { innovations }\end{array}$ & $\begin{array}{l}\text { Expenditures on machinery and } \\
\text { equipment (e.g. computers for automation or } \\
\text { control of the production process, industrial } \\
\text { robots and manipulators, machining centers, } \\
\text { computer-controlled production lines, } \\
\text { automatically controlled production lines, } \\
\text { modernized the production line, used other } \\
\text { specialized devices and tools), } \\
\text { Expenditures on ICT (e.g. install a server, } \\
\text { access the Internet using a broadband } \\
\text { connection, create an internal LAN Aetwork, } \\
\text { create an internal wireless network, create an } \\
\text { internal intranet, join an external extranet, use } \\
\text { voice over IP or ERP, enable remote access to } \\
\text { resources companies), } \\
\text { Expenditures on intellectual property } \\
\text { protection (e.g. to acquire a license, patent or } \\
\text { buy a new technological thought, develop utility } \\
\text { models, develop a trademark, create technical } \\
\text { knowledge in the form of know-how, create or } \\
\text { buy new computer software), } \\
\text { Expenditures on training (training focused } \\
\text { on the development and / or implementation of } \\
\text { new products / processes / organizational } \\
\text { solutions), } \\
\text { Expenditures on marketing activities } \\
\text { (internal or external marketing activities aimed } \\
\text { at ensuring that the market gets to know new } \\
\text { products (including preliminary market } \\
\text { research, initial advertising, excluding the } \\
\text { construction of the distribution network)), } \\
\text { Expenditures on the implementation of } \\
\text { new solutions (design and preparation } \\
\text { activities, develop new procedures to implement } \\
\text { new products, processes or organizational } \\
\text { solutions) }\end{array}$ & $\begin{array}{l}1 \text { - expended } \\
0 \text { - not expended }\end{array}$ & $\begin{array}{l}\text { [Oslo Manual, } \\
\text { 2005:29; PARP, } \\
\text { 2007:23-24; } \\
\text { Doloreux and } \\
\text { Dionne,2008; } \\
\text { Vaz et al., 2014; } \\
\text { Report "Badanie } \\
\text { wpływu...", } \\
\text { 2009] }\end{array}$ \\
\hline $\begin{array}{l}\text { The innovation } \\
\text { range }\end{array}$ & $\begin{array}{l}\text { An innovative company is a one that has } \\
\text { implemented new or significantly improved } \\
\text { solutions in relation to the process and / or } \\
\text { product (or service) and / or marketing and / } \\
\text { or organization in the last six years. } \\
\text { A non-innovative company is one that } \\
\text { hasn't implemented new or significantly } \\
\text { improved solutions in relation to the process and } \\
\text { / or product (or service) and / or marketing } \\
\text { and / or organization in the last six years. }\end{array}$ & $\begin{array}{l}1 \text { - implemented a } \\
\text { minimum of } 1 \text { type } \\
\text { of innovation } \\
0 \text { - did not } \\
\text { implement any } \\
\text { innovation }\end{array}$ & $\begin{array}{l}\text { [Oslo Manual, } \\
\text { 2005:8] }\end{array}$ \\
\hline
\end{tabular}

